\title{
Reproductive Traits and Somatic Growth of Diplodus sargus sargus (Linnaeus, 1758) in the Central Algerian Coast (Southern Mediterranean Sea)
}

\author{
Bilal Boufekane ${ }^{1, *}$ (D), Nadia Chakroun-Marzouk ${ }^{\text {(D) }}$, Elyes Kelai ${ }^{1,3}$ (D), Zakia Alioua ${ }^{1}$ (D) \\ Soumia Amira ${ }^{1}$ (D) Kamel Harchouche ${ }^{1}$
}

\begin{abstract}
${ }^{1}$ University of Science and Technology Houari Boumediene, Faculty of Biological Sciences, Fisheries Laboratory, Bab Ezzouar, El-Alia, PO Box 32, 16111, Algiers, Algeria.

${ }^{2}$ University of Tunis El Manar, Faculty of Sciences of Tunis, Biology Department, Fundamental and Applied Ichthyology Laboratory, 2092 El Manar II, Tunis, Tunisia.

${ }^{3}$ Center for Scientific and Technical Research in Physico-Chemical Analysis, Zone Industrielle PO Box 384, 42004 Bou-Ismail, Tipaza, Algeria.
\end{abstract}

\section{How to cite}

Boufekane, B., Chakroun-Marzouk, N., Kelai, E., Alioua, Z., Amira, S., Harchouche (2021). Reproductive Traits and Somatic Growth of Diplodus sargus sargus (Linnaeus, 1758) in the Central Algerian Coast (Southern Mediterranean Sea). Turkish Journal of Fisheries and Aquatic Sciences, 21, 381-399. http://doi.org/10.4194/1303-2712-v21_8_03

\section{Article History}

Received 26 October 2020

Accepted 14 May 2021

First Online 24 May 2021

\section{Corresponding Author}

Tel.: +213553751323

E-mail: boufekanebillel@gmail.com

\section{Keywords}

Diplodus sargus sargus

Reproductive cycle

Length-weight relationship

Size at maturity

\begin{abstract}
This work provides useful knowledge on the reproductive traits and somatic growth of the white seabream (Diplodus sargus sargus Linnaeus, 1758) of the central sector of the Algerian coast. It aimed to estimate the maximum yield size of this sparid and evaluate its reproductive potential, by presenting the first results on its global fecundity. A total of 497 specimens, ranging in size from 12.4 to $40.3 \mathrm{~cm}$, were monthly and randomly sampled from the artisanal fishery fleet, between January and December 2017. The obtained length-weight relationships indicated negative allometry for males ( $T W=0.024 \mathrm{TL}^{2.842}$ ) and isometry for females ( $T W=0.016 \mathrm{TL}^{3.013}$ ). The white seabream is a digynic protandrous hermaphrodite species. Sex reversal was observed with a large size overlap of 12 to $32 \mathrm{~cm}$ with a median of $23.5 \mathrm{~cm}$. The reproductive season was observed from January to May and spawning occurred in spring. The size at first sexual maturity $\left(\mathrm{TL}_{50}\right)$ was $20.55 \mathrm{~cm}$ for both sexes. Based on these results, the current legal minimum size of capture should be raised in the study area.
\end{abstract}

\section{Introduction}

Among fishery resources available on the Algerian coast, Sparidae are well represented both by diversity and production. Their high culinary and market value illustrate the crucial role that they play in the country's blue economy. Furthermore, catches exceeded 2725 tons in 2015, according to statistics from the Ministry of Fisheries and Fishery Resources (MPRH, 2017). The Diplodus genus constitutes one part of this large Sparidae family with five species found on the Algerian coast, constituting a great source of protein for this region. Among them, the high-valued subspecies $D$. sargus sargus is very common and widely distributed throughout the Mediterranean Sea, the Atlantic and
Indian Oceans, the Gulf of Arabia, and the Black Sea (Fischer et al., 1987; Louisy, 2015; Tortonese \& Cautis, 1967; Whitehead et al., 1986). This species is demersal and coastal, living on rocky and sandy bottoms throughout the continental shelf from 1 to $50 \mathrm{~m}$ in the Mediterranean Sea (Fischer et al., 1987) to $160 \mathrm{~m}$ in the Atlantic Ocean (Bauchot \& Hureau, 1986). Juveniles occupy shallow waters, while adults prefer deep rocky areas covered with algae (Harmelin-Vivien, M. et al., 1995; Louisy, 2015; Sala \& Ballesteros, 1997; Vigliola \& Harmelin-Vivien, 2001). Because of its commercial value, many researchers have studied some of the reproductive aspects of the white seabream in the Mediterranean Sea (Abou-Seedo et al., 1990; Benchalel, 2010; El-Maghraby et al., 1981, 1982); Giacalone et al., 
2018; Man-Wai, 1985; Martinez-Pastor \& VillegasCuadros, 1996; Micale et al., 1987; Micale \& Perdichizzi, 1994; Mouine et al., 2007, 2012), South Africa (Mann \& Buxton, 1998), and the Atlantic Ocean (Morato et al., 2003; Pajuelo \& Lorenzo, 2004). Like most hermaphroditic species of Sparidae, the reproductive strategy of the white seabream is quite complex due to the flexibility of its sexual expression. Knowledge related to the dynamics of its reproduction and renewal is important and plays a crucial role in fishery management and in the assessment of its exploitation level. This work provides original, complete, and updated data on the reproductive biology and somatic growth of the exploited stock of $D$. sargus sargus in the central region of the Algerian coast. It aimed to (1) determine and analyse the length-weight relationships using the cube law, (2) characterise sex changes and the sex ratio across months, seasons, and sizes, (3) identify the spawning season, (4) study its biophysiology and report its reproductive load, (5) estimate its length at first maturity and the size of maximum yield, and (6) evaluate the reproductive potential of the white seabream, by presenting the first results on its fecundity.

\section{Materials and Methods}

\section{Study Area and Sampling}

Reproduction of the white seabream was studied on 497 specimens, monthly and randomly collected between January and December 2017 by commercial fisheries. The samples came from artisanal fishing ventures (trammel and longlines) in several ports (Cherchell, Tipaza, Bouharoun, El Djamila, Algiers, and Tamentfoust) along the central Algerian coast. The sample area extended from Tenes ( $36^{\circ} 34^{\prime} 44^{\prime \prime} \mathrm{N} ; 1^{\circ} 18^{\prime}$ $\left.16^{\prime \prime} \mathrm{E}\right)$ to Dellys ( $36^{\circ} 54^{\prime} 48^{\prime \prime} \mathrm{N} ; 3^{\circ} 54^{\prime} 51^{\prime \prime} \mathrm{E}$ ) (Figure 1). For each specimen, the following linear and weight measurements were taken in the laboratory: total length ( $T L$ in $\mathrm{cm}$ ), total weight ( $T W$ in $\mathrm{g}$ ), gonad weight (GW in g), liver weight (LW in g), and eviscerated weight (EW in g). Sea surface temperature (SST) data were provided from the NOAA Extended Reconstructed Sea Surface Temperature (ERSST) (NOAA, 2017) derived from the improvements made in the use of updated COADS observations with new quality control procedures and reconstruction methods described in Smith \& Reynolds (2003) and Xue et al. (2003) (Table 1).

\section{Length-weight Relationship (LWR)}

The length-weight relationship (TW=a TL $\left.{ }^{b}\right)$ was calculated for each sex (males, females, and hermaphrodites) and for pooled sexes. For the estimation of the parameters $a$ and $b$, they were converted into their logarithmic linear regression ( $\log a$ $+b \log \mathrm{TL})$ by the least squares' method. The null hypothesis of isometric growth $\left(\mathrm{H}_{0}: b=3\right)$ was tested by a t-test $\left(t_{s}\right)$ via FSA and FSAdata packages (Ogle, 2019; Ogle et al., 2019) using the formula: $t_{s}=(b-3) / S_{b}$, where $S_{b}$ is the standard error of the slope with a risk of $\alpha=0.05$. The coefficient of determination $\left(r^{2}\right)$ was calculated to estimate the association degree between length and weight variables. The maximum growth rate in weight, after which fishes may be caught, was calculated according to the empirical method of Froese et al. (2008), corresponding to 0.67 of the maximum length of fish.

\section{Sex Identification and Macroscopic Scale of Gonads}

Sex was identified by visual examination of the gonads after dissection. The ovaries were cylindrical, coloured from translucid, yellow, orange to reddish orange, following the development of the ovogenesis cycle. The testicles were whitish and flattened into an irregular lamina shape. Moreover, hermaphrodite individuals with an ovotestis were identified; male and female territories of the bisexual gonad may occur in

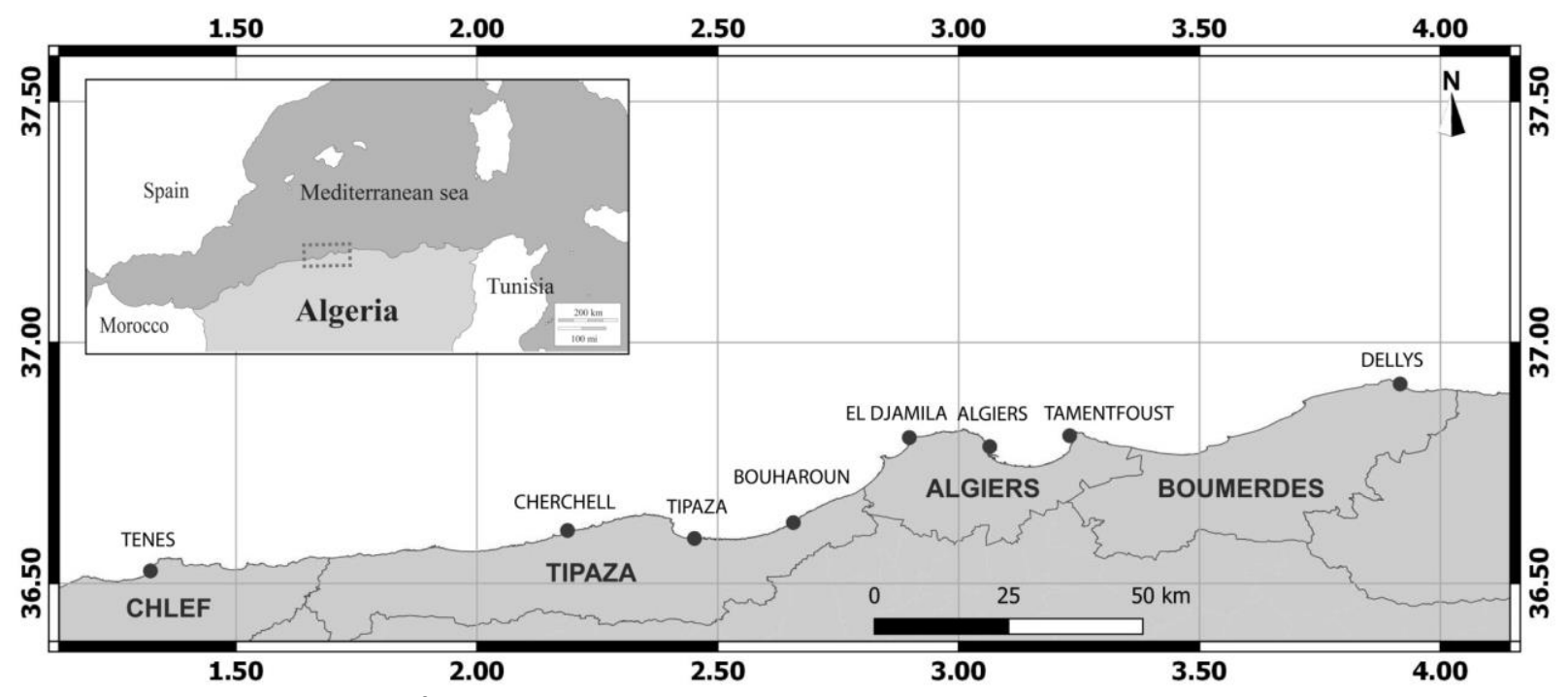

Figure 1. Geographical location of the study area 
Table 1. Monthly mean total length (TL), mean total weight (TW) of $D$. sargus sargus collected between January and December 2017 and sea surface temperature (SST) with their standard deviations (SD).

\begin{tabular}{lcccc}
\hline Months & $\mathbf{n}$ & TL \pm SD $(\mathbf{c m})$ & TW \pm SD $(\mathbf{c m})$ & SST \pm SD $\left({ }^{\circ} \mathbf{C}\right)$ \\
\hline January & 27 & $20.01 \pm 2.38$ & $140.68 \pm 66.70$ & $13.13 \pm 2.36$ \\
February & 58 & $21.11 \pm 5.64$ & $208.93 \pm 231.11$ & $15.81 \pm 2.19$ \\
March & 72 & $23.63 \pm 3.42$ & $243.06 \pm 101.32$ & $16.47 \pm 2.38$ \\
April & 83 & $23.8 \pm 3.77$ & $254.69 \pm 157.84$ & $17.56 \pm 2.39$ \\
May & 21 & $24.67 \pm 3.52$ & $280.23 \pm 123.47$ & $20.22 \pm 1.86$ \\
June & 7 & $20.41 \pm 0.65$ & $148.43 \pm 14.86$ & $23.68 \pm 2.30$ \\
July & 18 & $22.78 \pm 2.98$ & $216.35 \pm 86.37$ & $26.27 \pm 2.06$ \\
August & 20 & $26.3 \pm 5.94$ & $357.15 \pm 230.53$ \\
September & 51 & $20.84 \pm 3.75$ & $173.26 \pm 115.35$ \\
October & 57 & $16.85 \pm 5.10$ & $113.72 \pm 141.43$ \\
November & 61 & $21.73 \pm 3.40$ & $194.19 \pm 98.39$ \\
December & 22 & $22.15 \pm 1.47$ & $174.02 \pm 48.60$ \\
Overall & 497 & $21.88 \pm 4.62$ & $208.27 \pm 151.39$ \\
\hline
\end{tabular}

$\mathrm{n}=$ sample size

equal proportions or one of them may be more developed than the other. Based on different observations of gonads in our sample, the morphological criteria of Albaret (1977) were adopted for establishing the scale of gonad maturation. They included the colour consistency and shape of the gonads, development of the vascularisation, thickness or transparency of the ovarian wall, volume occupied by the gonad in the abdominal cavity, and visibility and aspect of oocytes through the ovarian wall. Then, a fivestage macroscopic scale of gonads was adopted as follows: stage I (immature), stage II (developing), stage III (spawning capable), stage IV (regressing), and stage V (regenerating) (Figure 2). Designation of the stages was inspired by the standardised terminology of BrownPeterson et al. (2011) for describing reproductive development in fish.

\section{Histological Study of Ovaries}

Female gonads were fixed in $10 \%$ buffered formalin, dehydrated by alcoholic solutions in a programmed automat, impregnated, and embedded in paraffin. Then, they were cut into $3 \mu \mathrm{m}$ sections with a Leica RM2125 RT microtome and stained with haematoxylin-eosin. Slides were examined by a Premiere T3.15A microscope, and photographs were taken with a Premiere Camera connected to a computer with ImageFocus 4 analysis software. The nucleocytoplasmic index (NI) ( $\mathrm{NI}=$ nucleus diameter / cytoplasm diameter) was established for the confirmation of microscopic stages of sexual maturity in females by monitoring the evolution of this ratio during the gamete maturation phase.

\section{Reproduction and Biophysiological Indices}

Numerical proportions of sexes were expressed as a relative percentage of the identified individuals (males, females, and hermaphrodites). The overall sex ratio expressed as male: female ratio and its variations were studied according to months, seasons, and sizes. Deviations from a 1:1 null hypothesis were statistically tested using the Chi-square analysis $\left(\chi^{2}\right)$. The reproductive period was determined by analysing the monthly variation in gonadal maturity stages, as well as the mean gonadosomatic index (GSI=GW / EW × 100). Correlation between GSI and SST was tested using Spearman's rank correlation coefficient ( $\mathrm{rho}_{\mathrm{s}}$ ). Fluctuations of lipid reserves in the liver and muscles were observed by monitoring the monthly variation in the mean hepatosomatic index $(\mathrm{HSI}=\mathrm{LW} / \mathrm{EW} \times 100)$ and condition factor ( $\left.\mathrm{K}=\mathrm{EW} / \mathrm{TL}^{3} \times 100\right)$, respectively. These indices are expressed with their confidence interval as follow: $m \pm t \times S D /(V n-1)$, where $m$ is the mean of indices (GSI, HSI and $\mathrm{K}$ ), $t$ is the value read from the Student table, $n-1$ is the degrees of freedom, SD is the standard deviation, and $\mathrm{n}$ is the sample size with a risk of $5 \%$ (Schwartz, 1983). The significance of the monthly variations of the mean values of previously mentioned indices was studied using the Kruskal-Wallis rank sum test, after checking the Shapiro-Wilk normality test. Pearson's correlation coefficient was used to examine the correlation between $\mathrm{GSI}, \mathrm{HSI}$, and $\mathrm{K}$.

\section{Sexual Expression}

To determine the sexual biotypology expression of the white seabream, the size frequency distribution of sexes was analysed. Moreover, the mean size and GSI of both sexes were estimated and compared as stated by Buxton and Garratt (1990). Moreover, for interpopulation comparisons, the median length of sexual inversion was evaluated using the Shapiro's (1984) method, which consisted of aggregating the frequency distribution of sizes where females and males overlap, then calculating the median (point 50\%).

\section{Size at First Maturity}

The length at first sexual maturity $\left(T_{50}\right)$ was estimated for males, females, and combined sexes from 


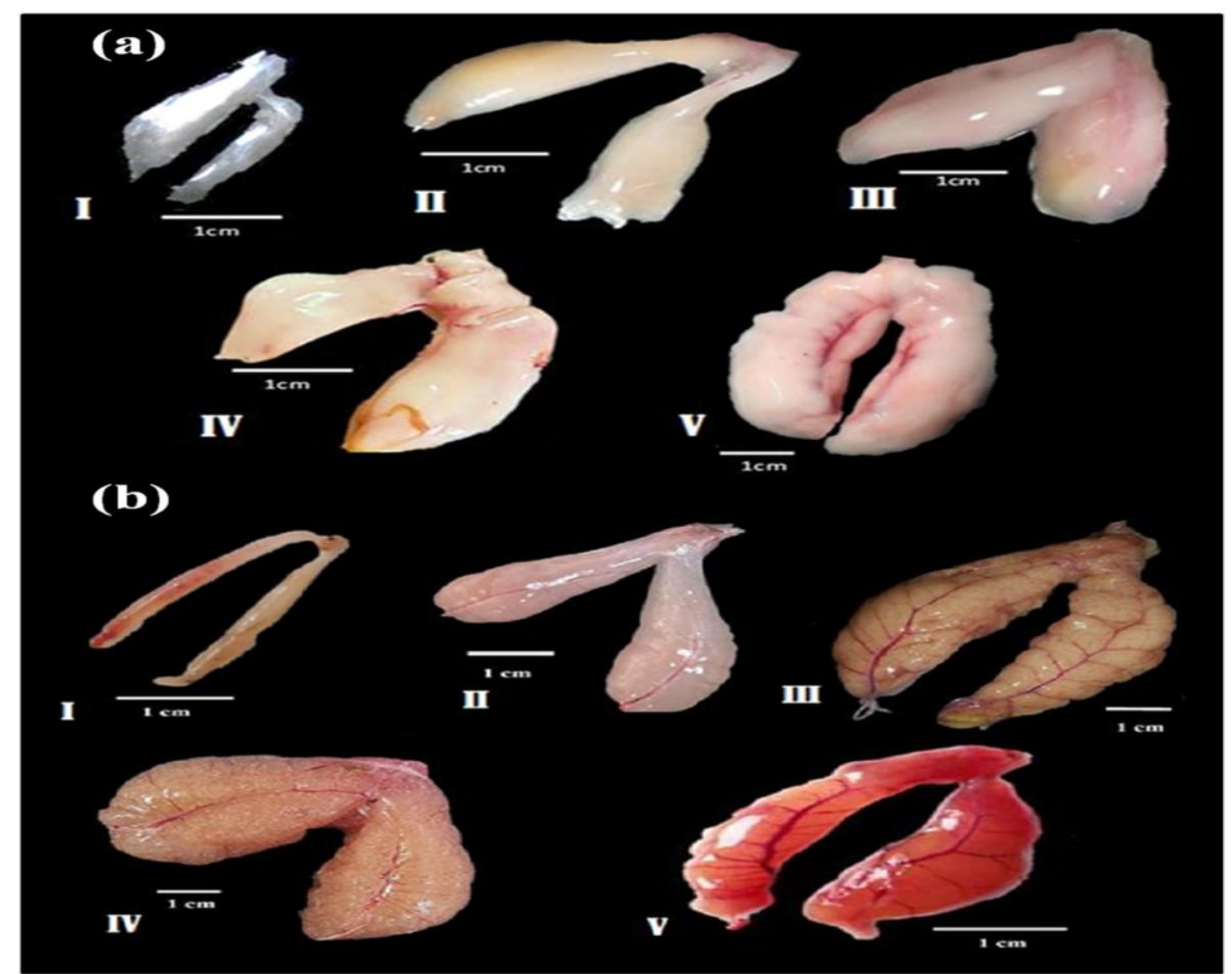

Figure 2. Macroscopic developmental stages of male (a) and female (b) gonads of the white seabream Diplodus sargus sargus. Stage I (immature), Stage II (developing), Stage III (spawning capable), Stage IV (regressing), Stage V (regenerating)

fishes collected only during the spawning season where the proportion of mature individuals was high and immature individuals were well and correctly identified. Determination of $\mathrm{TL}_{50}$ was established by the logistic function that is usually used in stock assessment models and fitted by a weighted non-linear least squares regression (Saila et al., 1988) as follows: $P=1 /\left(1+\mathrm{e}^{-b \text { (TL }}\right.$ ${ }^{-T L 50)}$ ), where $P$ is the proportion of mature individuals, $\mathrm{TL}$ is the total length of fish in $\mathrm{cm}, \mathrm{TL}_{50}$ is the size at which $50 \%$ of the fish are mature, and $b$ is the slope of the maturity curve. Individuals with gonads were consistent with stages II (developing), III (spawning capable), and IV (regressing) and were considered mature. The $t$-test was used to compare the logistic model parameter estimates between males and females. The length at which $100 \%$ of the individuals reached sexual maturity $\left(T_{100}\right)$ was extrapolated from the obtained logistic curve for combined sexes. The ratio $\mathrm{TL}_{50} / \mathrm{TL}_{\max }$, which approximated the reproductive load of $D$. sargus sargus, was calculated using $\mathrm{TL}_{50}$ as the length at which $50 \%$ of the population became mature for the first time and $T L_{\max }$ as the maximum length reached in the sample (Longhurst \& Pauly, 1987).

\section{Fecundity}

Fecundity was determined from oocytes in advanced maturity stages before egg laying and found in ovaries at stages II, III, and IV, as usually adopted for multiple spawners (Amira et al., 2019; Boufersaoui \& Harchouche, 2015). The fecundity of the white seabream was assessed by the volumetric method, expressed in Kartas and Quignard, 1984, in 43 females ranging between 21.3 and $40.3 \mathrm{~cm}$ total length and whose gonads were stored in Gilson liquid, which has a shrinking effect on oocytes. The oocytes of 18 matures females were placed in a petri dish and 2,886 oocyte diameters were measured to determine the filter mesh to be used for the removal of the current year's reserve eggs. The oocyte diameter size frequency distribution was also established to determine the type of ovarian development organisation and the spawning pattern (Murua \& Saborido-Rey, 2003). A one-way ANOVA was used to test the mean oocyte diameter within the same lobe and between ovarian lobes, and to compare oocyte diameter means between distinct batches. The post-hoc Tukey's HSD test was performed to determine pair-wise differences. The absolute fecundity ( $\mathrm{Fa}$ ) was defined as the total number of eggs released by a mature female; for correct oocyte counting, each whole ovary was regularly shaken to separate eggs from the ovarian wall, this operation was followed by filtration to remove the reserve oocytes. Oocytes retained by the filter were placed in a beaker, and the volume was adjusted to 200 $\mathrm{mL}(\mathrm{V})$. While continuous agitation kept the oocytes in a homogeneous suspension, two sub-samples of $10 \mathrm{~mL}$ (v) were collected, and each was sedimented in a Dollfus tank with 100 cells. For each of them, the egg count was carried out on 10 box oocytes taken at random, under a binocular microscope equipped with a camera (Cam, 5 Megapixel, Premiere) connected to a computer with Image Focus 4 analysis software. The average number of eggs of the two sub-samples was used to calculate absolute fecundity (Fa) by egg-laying from the following 
formula: $F a=n \times 20 \times V / v$, where $n$ is the number of counted oocytes contained in the 10 cells, $V$ is the total volume of oocyte-water mixture, and $v$ is the volume of the sub-sample taken. The average absolute fecundity (Fa) was expressed with its confidence interval as follows: Fa $\pm t \times \mathrm{SD} /(\mathrm{V} \mathrm{n}-1)$, where $t$ is the value read from the Student table, $n-1$ is the degrees of freedom, $\mathrm{SD}$ is the standard deviation, and $\mathrm{n}$ is the sample size with a risk of $5 \%$ (Schwartz, 1983). The relationships between absolute fecundity (Fa), total length (TL), total weight (TW) and gonad weight (GW) were then evaluated using linear regression and powers of least square and least rectangle types. Pearson's correlation coefficient ( $r$ ) was applied to examine the significance between the absolute fecundity ( $\mathrm{Fa}$ ) and the three studied parameters (TL, TW, and GW). Relative fecundity (Fr) was estimated as the number of mature oocytes per gram of female body weight. It was based on the principle of Oosthuizen and Daan, 1974, which used the regression coefficient (a) of the $F a=f(T W)$ relationship as an index of relative fecundity whose confidence interval limits $\left(a_{1}\right.$ and $\left.a_{2}\right)$ were at a $5 \%$ risk of errors, as determined by the following Dagnelie's formulas, (1984):

$$
\begin{aligned}
& a_{1}<a \times V\left(1+2 K-V\left((1+2 K)^{2}-1\right)\right) \\
& a_{2}=a \times v\left(1+2 K+v\left((1+2 K)^{2}-1\right)\right)
\end{aligned}
$$

Where $a$ is the regression coefficient of the least rectangle line, $r$ is the correlation coefficient of the line, $K$ is equal to $\left(t^{2}(1-\alpha .2-1) \times\left(1-r^{2}\right)\right) /(n-2), t$ is the value read on the Student table, $n-2$ is the degrees of freedom (df; $n$ : number of weight classes), and $\alpha$ is equal to $5 \%$. The determination of the overall reproductive capacity of the $D$. sargus sargus population in the central Algerian coast was established based on the biological data and demographic structure of the exploited stock, previously assessed as the sex ratio distribution by size class during the spawning period, absolute fecundity, and size at first sexual maturity. The combination of these elements led to a curve of egg production according to size, which determined the contribution of a given size class to the species' reproduction (Fontana \& Le Guen, 1969).

All statistical treatments of the study were performed by R software version 3.6.1 (R Core Team, 2019).

\section{Results}

\section{Sample Composition and Length-weight Relationship}

Among the 497 individuals, 64 were immature fish (TL: 13.4 to $24.5 \mathrm{~cm}$ ), 190 were males (TL: 12.4 to 31.1 $\mathrm{cm}$ ), 151 were females (TL: 13.4 to $40.3 \mathrm{~cm}$ ), and 92 were hermaphrodites (TL: 17.7 to $29.3 \mathrm{~cm}$ ). The mean length of immature individuals $(20.56 \pm 1.54 \mathrm{~cm})$ was significantly lower (Kruskal-Wallis rank sum test, $\mathrm{H}=6.089, \mathrm{df}=251, \mathrm{P}<0.001)$ than that of males $(T L=21.53 \pm 0.28 \mathrm{~cm})$, females $(23.7 \pm 0.43 \mathrm{~cm})$ (KruskalWallis rank sum test, $\mathrm{H}=8.425, \mathrm{df}=211, \mathrm{P}<0.001$ ), and hermaphrodites $(22.6 \pm 0.28 \mathrm{~cm}$ ) (Kruskal-Wallis rank sum test, $\mathrm{H}=7.094, \mathrm{df}=152, \mathrm{P}<0.001)$. Female and male mean sizes were significantly different (Kruskal-Wallis rank sum test, $\mathrm{H}=3.449, \mathrm{df}=339, \mathrm{P}<0.05)$. Males were significantly more numerous in the sample (43.88\%), followed by females (34.87\%) and only a smaller percentage of the population was devoted to bisexual individuals $(21.25 \%)$ identifiable to the naked eye. Length-weight regression parameters estimated for males, females, hermaphrodites, unsexed, and combined sexes are presented in Table 2; they were highly significant (ANOVA, $\mathrm{P}<0.001$ ) in the five groups. Male somatic growth showed a negative allometry ( $t$ test, $P=0.0038$ ) but isometry for females, hermaphrodites, unsexed, and pooled sexes ( $t$-test, $\mathrm{P}=0.963,0.879,0.929$, and 0.874 , respectively). In addition, there were no significant differences between the slopes of the regressions of males and females (ANCOVA, $n=341, \mathrm{P}>0.001$ ). Furthermore, the somatic growth of white seabream was isometric for females during all seasons ( $t$-test, reproductive season $\mathrm{P}=0.885$, spawning $\mathrm{P}=0.871$, and regressing $\mathrm{P}=0.898)$, while for

Table 2. Parameters of length-weight relationships for males, females, hermaphrodites, unsexed and pooled sexes of $D$. sargus

\begin{tabular}{|c|c|c|c|c|c|c|c|c|c|c|}
\hline Sex & $a$ & $b$ & $\mathbf{n}$ & SE $(b)$ & \multicolumn{2}{|r|}{$r^{2}$} & $t$ & $\mathbf{P}$ & \multicolumn{2}{|c|}{ Type of growth } \\
\hline$M$ & 0.024 & 2.842 & 190 & 0.017 & \multicolumn{2}{|r|}{0.987} & 9.218 & 0.0038 & \multicolumn{2}{|r|}{----} \\
\hline $\mathrm{F}$ & 0.016 & 3.013 & 151 & 0.027 & \multicolumn{2}{|r|}{0.989} & 1.863 & 0.963 & \multicolumn{2}{|r|}{ Isometry } \\
\hline $\mathrm{H}$ & 0.021 & 2.934 & 92 & 0.024 & \multicolumn{2}{|r|}{0.991} & 2.748 & 0.879 & \multicolumn{2}{|r|}{ Isometry } \\
\hline U & 0.026 & 2.954 & 64 & 0.028 & \multicolumn{2}{|r|}{0.989} & 2.343 & 0.929 & \multicolumn{2}{|r|}{ Isometry } \\
\hline All fish & 0.021 & 2.948 & 497 & 0.015 & \multicolumn{2}{|r|}{0.990} & 2.395 & 0.874 & \multicolumn{2}{|r|}{ Isometry } \\
\hline Period & & Sex & $a$ & $b$ & $\mathbf{n}$ & SE $(b)$ & $r^{2}$ & $t$ & $\mathbf{P}$ & Type of growth \\
\hline \multirow{2}{*}{\multicolumn{2}{|c|}{$\begin{array}{l}\text { Reproductive period } \\
\text { (January - May) }\end{array}$}} & $\mathrm{M}$ & 0.012 & 3.199 & 100 & 0.032 & 0.988 & 6.932 & 0.0091 & +++ \\
\hline & & $\mathrm{F}$ & 0.013 & 3.047 & 86 & 0.025 & 0.987 & 1.748 & 0.885 & Isometry \\
\hline \multirow{2}{*}{\multicolumn{2}{|c|}{$\begin{array}{l}\text { Spawning/emision } \\
\text { (March - May) }\end{array}$}} & M & 0.025 & 2.886 & 64 & 0.014 & 0.981 & 5.517 & 0.0324 & ---- \\
\hline & & $\mathrm{F}$ & 0.015 & 3.043 & 68 & 0.029 & 0.983 & 2.238 & 0.871 & Isometry \\
\hline \multirow{2}{*}{\multicolumn{2}{|c|}{$\begin{array}{l}\text { Resting } \\
\text { (June - December) }\end{array}$}} & $M$ & 0.028 & 2.843 & 90 & 0.019 & 0.991 & 7.949 & 0.0043 & ---- \\
\hline & & $\mathrm{F}$ & 0.021 & 2.963 & 65 & 0.022 & 0.986 & 1.932 & 0.898 & Isometry \\
\hline
\end{tabular}
sargus and parameters of the LWRs of males and females with reproductive period in the central Algerian coast.

$\mathrm{M}=$ males, $\mathrm{F}=$ females, $\mathrm{H}=$ hermaphrodites, $\mathrm{U}=$ unsexed, $a=$ intercept, $b=$ slope, $\mathrm{n}=$ sample size, $\mathrm{SE}(b)=$ standard error of slope $b$, $r^{2}=$ determination coefficient, $t=$ value of Student test, $\mathrm{P}=p$.value of $t$-test $\left(\mathrm{H}_{0}: \mathrm{b}=3\right),++++=$ positive allometry, $----=$ negative allometry. 
males a positive allometry was detected in the emission period ( $t$-test, $\mathrm{P}=0.0091$ ) and a negative allometry at spawning ( $t$-test, $\mathrm{P}=0.0324)$ and in the resting periods ( $t$ test, $\mathrm{P}=0.0043$ ) (Table 2).

\section{Sex Ratio, Sex Reversal, and Length at First Maturity}

The overall sex ratio (Table 3) was 1 male to 0.79 females diverging significantly from $1: 1 \quad\left(\chi^{2}\right.$ Test, $\left.M: F=1: 0.79, n=341, \chi^{2}=8.469, P<0.05\right)$. The sex ratio of the resting period (June to December) was dominated by males ( $\left.M: F=1: 0.72, n=155, \chi^{2}=7.432, P<0.05\right)$, but during spawning (March to May), the number of males was almost equal to that of females ( $M: F=1: 1.06, n=132$, $\left.\chi^{2}=0.136, \quad P>0.05\right)$. Moreover, the seasonal sex distribution was in favour of males, highlighted mainly by stages I and III in winter (M:F=1:0.49, $n=73, \chi^{2}=15.78$, $\mathrm{P}<0.05)$. However, for the other seasons, the ratio of male to female did not show a predominance of either sex. Otherwise, the variation in sex ratio according to size showed that males clearly dominated in [12-24 cm length-classes ( $\left.M: F=1: 0.57, n=232, \chi^{2}=34.216, P<0.001\right)$, while females were most abundant in the above $24 \mathrm{~cm}$ length-classes ( $\mathrm{M}: \mathrm{F}=1: 1.60, \mathrm{n}=109, \mathrm{X}^{2}=10.569, \mathrm{P}<0.001$ ). In terms of sex frequency distribution with size, a predominance of males was registered in smaller size classes, a presence of bisexual individuals was noted in intermediate sizes (12 and $32 \mathrm{~cm})$, and a clear dominance of females was observed in the larger size classes (Figure 3) with all individuals larger than $32 \mathrm{~cm}$ being females. Sex reversal was observed in a large size overlap of 12 to $32 \mathrm{~cm}$ (Figure 4a). The estimated median total length of sex inversion by means of Shapiro's method was $23.5 \mathrm{~cm}$ (TL) (Figure 4b). Regarding the established maturation scale of gonads, no male or female was mature below $19 \mathrm{~cm}$ of total length (TL). The sizes at which $50 \%$ of males and females of $D$. sargus sargus were sexually mature were $21.05 \pm 0.25 \mathrm{~cm}$ and $19.75 \pm 0.15 \mathrm{~cm} \mathrm{TL}$, respectively. Since no significant difference in length at first maturity $\left(T L_{50}\right)$ was found between sexes ( $t$-test, $P>0.05$ ), data were grouped and the resulting $\mathrm{TL}_{50}$ for pooled sexes was $20.55 \pm 0.19 \mathrm{~cm}$ (Figure 5). The length at which $75 \%$ of individuals were mature was $22.65 \pm 0.13 \mathrm{~cm}$, while the size at which $25 \%$ of individuals were mature was $18.65 \pm 0.19 \mathrm{~cm}$. The size at total maturity, which is the size at which $100 \%$ of individuals were mature, was $30.75 \mathrm{~cm}\left(\mathrm{TL}_{100}\right)$. The estimated reproductive load of the white seabream of the central Algerian coasts was 0.51 .

\section{Macroscopic Stages of Gonad Maturity}

All gonads were assessed macroscopically, as well as sex and gonad maturity stage. Maturity was assigned to each sampled individual (Table 4). The monthly evolution of maturity stages of gonads (Figure 6) showed an earlier spawning period for males (January to April; Figure 6b) than for females (February to April, Figure 6a). Immature individuals (stage I; Table 4, Figures $2 a$ and $2 b$ ) were present in most months for both sexes, before and after the spawning period. Males and females with developing gonads (stage II; Table 4, Figures $2 \mathrm{a}$ and $2 \mathrm{~b}$ ) were recorded between January and December (57\%; Figure 6a) and between August and June (45\%; Figure 6b), respectively. Mature specimens (stage III; Table 4, Figures 2a and 2b) were encountered during the sexual activity period from January to May, and they were more dominant from February to March for males (Figure 6b) and from March to April for females (Figure 6a). After the spawning period, most of

Table 3. Seasonal, monthly and sexual variations of the sex ratio (female: male) of D. sargus sargus in the central Algerian coast.

\begin{tabular}{|c|c|c|c|c|c|c|c|}
\hline $\begin{array}{l}\text { Seasons / Months } \\
\text { Reproductive period }\end{array}$ & M & $\mathbf{F}$ & $T$ & SR & $x^{2}$ & $\mathbf{P}$ & Significance \\
\hline Winter & 49 & 24 & 73 & 1:0.49 & 15.78 & $7.1110^{-5}$ & S \\
\hline December & 13 & 6 & 19 & 1:0.46 & 3.7895 & 0.052 & NS \\
\hline January & 17 & 1 & 18 & 1:0.06 & 25 & $5.7310^{-7}$ & $S$ \\
\hline February & 19 & 17 & 36 & $1: 0.89$ & 0.055 & 0.814 & NS \\
\hline Spring & 64 & 68 & 132 & $1: 1.06$ & 0.136 & 0.712 & NS \\
\hline March & 24 & 23 & 47 & $1: 0.96$ & 0.0053 & 1 & NS \\
\hline April & 34 & 37 & 71 & 1:1.09 & 0.113 & 0.737 & NS \\
\hline May & 6 & 8 & 14 & $1: 1.33$ & 0.143 & 0.706 & NS \\
\hline Summer & 22 & 17 & 39 & 1:0.77 & 0.821 & 0.365 & NS \\
\hline June & 3 & 4 & 7 & $1: 1.33$ & 0 & 1 & NS \\
\hline July & 10 & 6 & 16 & 1:0.6 & 1.125 & 0.289 & NS \\
\hline August & 9 & 7 & 16 & $1: 0.78$ & 0.125 & 0.724 & NS \\
\hline Autumn & 55 & 42 & 97 & 1:0.74 & 2.969 & 0.085 & NS \\
\hline September & 16 & 12 & 28 & 1:0.75 & 0.643 & 0.428 & NS \\
\hline October & 18 & 7 & 25 & $1: 0.39$ & 8 & 0.004 & $S$ \\
\hline November & 21 & 23 & 44 & 1:1.1 & 0.045 & 0.831 & NS \\
\hline $\begin{array}{l}\text { Reproductive period } \\
\text { (January to May) }\end{array}$ & 100 & 86 & 186 & $1: 0.86$ & 1.817 & 0.1776 & NS \\
\hline Resting period (June to December) & 90 & 65 & 155 & $1: 0.72$ & 7.432 & 0.0064 & $\mathrm{~S}$ \\
\hline Overall & 190 & 151 & 341 & $1: 0.79$ & 8.469 & 0.0036 & $S$ \\
\hline
\end{tabular}




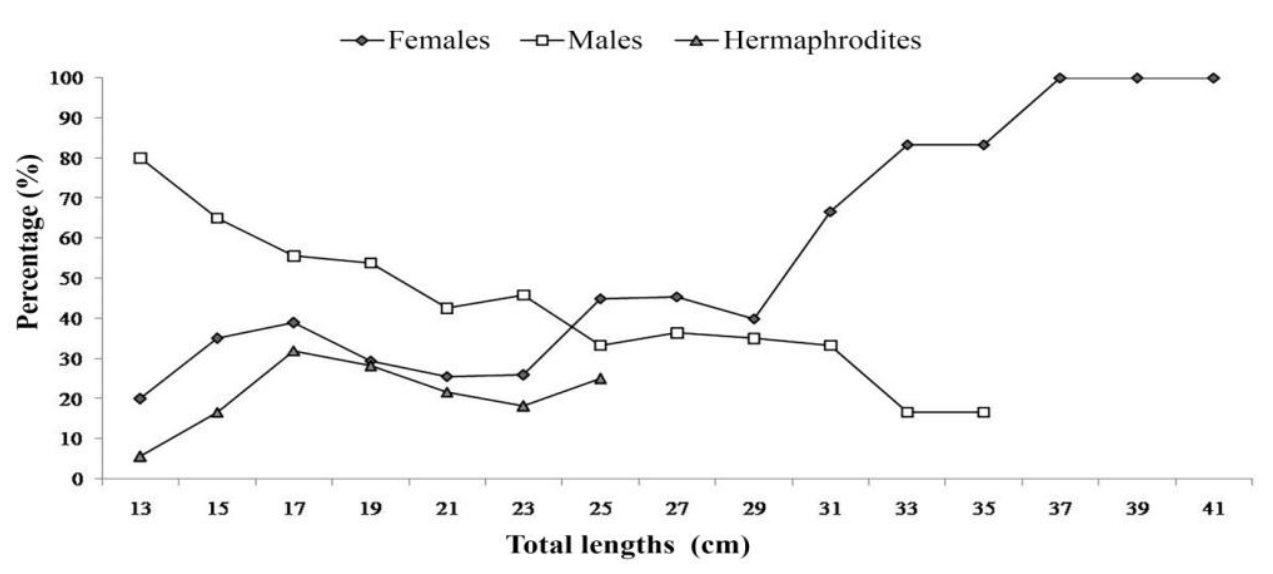

Figure 3. Sex frequency distribution of $D$. sargus sargus with size

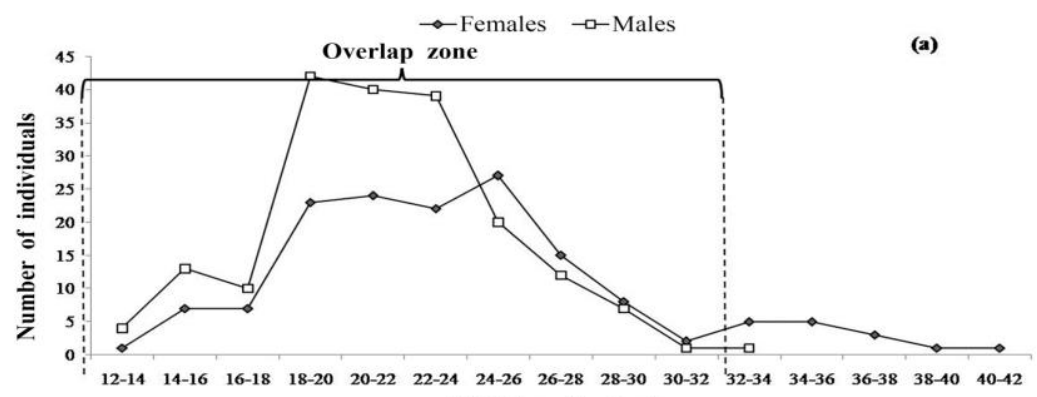
Total lengths $(\mathrm{cm})$

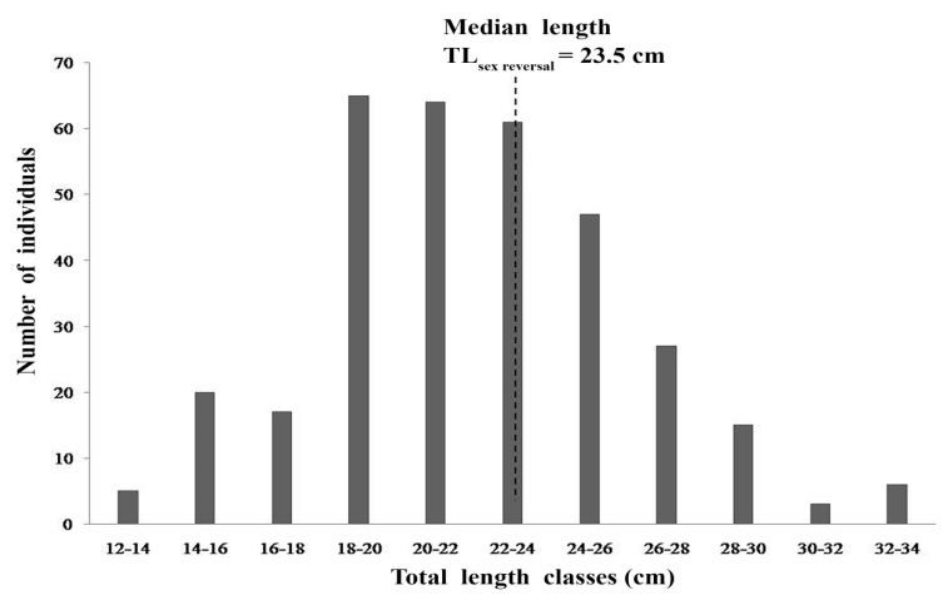

Figure 4. Sex reversal and schematic representation of the sex size-frequency overlap distributions of $D$. sargus sargus in the central Algerian coast

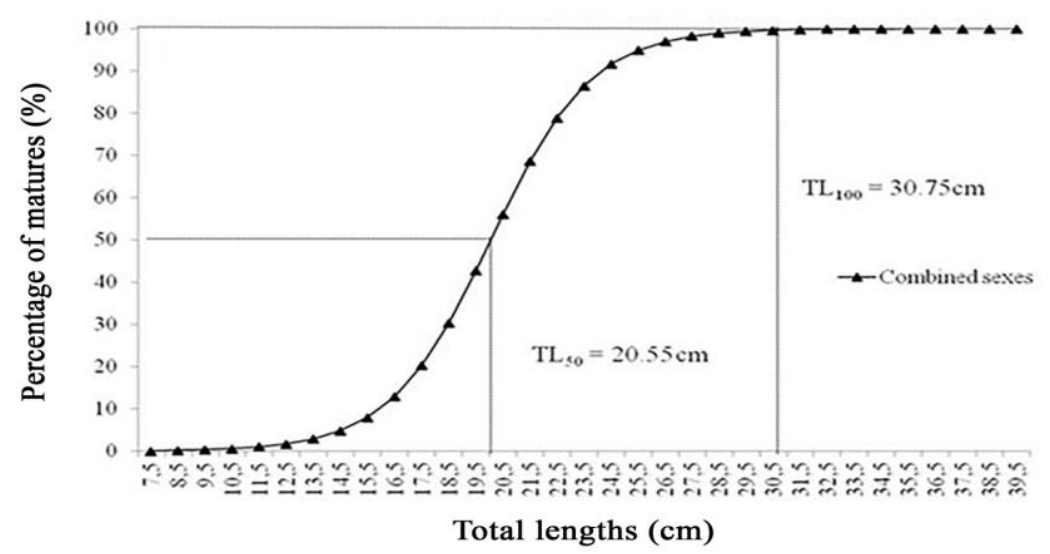

Figure 5. Size at first maturity $T L_{50}$ for combined sexes of $D$. sargus sargus. $T L_{100}$ : length at total maturity 
the regressing specimens (stage IV; Table 4, Figures 2a and $2 \mathrm{~b}$ ) were observed in May (Figures $6 \mathrm{a}$ and $6 \mathrm{~b}$ ) and then returned to the regenerating stage (stage $\mathrm{V}$; Table 4 , Figures $2 a$ and $2 b$ ).

\section{Histological Analysis}

Examination of histological sections of ovaries showed different maturity stages (Table 5; Figure 7). Immature females were characterised by the presence of oogonia (Oog) and primary growth oocytes (PG) (Figure 7a). The developing stage showed the appearance of primary and secondary vitellogenic oocytes (Vtg1 and Vtg2) (Figure 7b and 7c). The spawning capable stage was distinguished by tertiary vitellogenic and germinal vesicle migration oocytes (Vtg3 and GVM) (Figures 7d and 7e). The last phases (regressing / regenerating), representing conditions at resting season, were characterised by the degenerative processes of follicles, as atresia (ATR) and postovulatory follicles (POFs) (Figure 7f). Additionally, the new presence of the first development stage, such as oogonia and primary growth oocytes (PG), were observed (Figure 7g).

\section{Reproductive Cycle}

The curves of GSI monthly values were unimodal for both males and female. They showed a synchronous evolution starting in February, which marked the beginning of spawning period for each sex (Figure 8a). GSI mean values began to increase sharply for males but only gradually for females. The GSI trend highlighted a peak in March for males $(4.59 \pm 0.79, n=24)$ and in April for females $(3.24 \pm 0.57, n=37)$, followed by an abrupt decline in May, marking the end of the sexual activity period for both sexes. The very low values observed between June and November indicated a return to the resting period. For this species, the reproductive period extended from late winter to spring for both sexes whereas the spawning period was concentrated in three months (March to May) for females and four months (February to May) for males. The mean gonadosomatic index varied significantly from one month to another for males (Kruskal-Wallis rank sum test, $\mathrm{H}=79.652$, $\mathrm{df}=11$, $\mathrm{P}<0.001$ ) and females (Kruskal-Wallis rank sum test, $\mathrm{H}=45.297, \mathrm{df}=11, \mathrm{P}<0.001$ ). The GSI versus SST monthly fluctuations (Figure 8a) showed that spawning occurred when the temperature began to increase gradually (16 $-20^{\circ} \mathrm{C}$ ) after its minimum values registered during the winter period. No significant negative correlations between GSI and SST were evident for both sexes (Spearman's rank test ( $r$ os $)$ : females: $r=-0.517, P>0.05$ and males: $r=-0.496, \quad P>0.05)$. The highest hepatosomatic index values were observed at the beginning of gonad maturation in both females $(1.75 \pm 0.23)$ and males (1.24 \pm 0.25$)$ (Figure $8 b)$. During the egg laying and semen emission period, this index

Table 4. Macroscopic description of the gonadal stages in the reproductive cycle of Diplodus sargus sargus females and males.

\begin{tabular}{|c|c|c|c|c|}
\hline \multirow[t]{2}{*}{ Stages } & \multicolumn{2}{|l|}{ Females } & \multicolumn{2}{|l|}{ Males } \\
\hline & Macroscopic features of ovaries & GSI \pm SE & $\begin{array}{l}\text { Macroscopic features of } \\
\text { testis }\end{array}$ & $\mathrm{GSI} \pm \mathrm{SE}$ \\
\hline Stage I: Immature & $\begin{array}{l}\text { Small ovaries, transparent, often clear } \\
\text { slightly pinkish and filamentous with very } \\
\text { fine vascularization. No oocytes visible } \\
\text { macroscopically. }\end{array}$ & $0.24 \pm 0.06$ & $\begin{array}{l}\text { Small and whitish testes, } \\
\text { often clear with a few } \\
\text { blood vessels. }\end{array}$ & $0.18 \pm 0.02$ \\
\hline $\begin{array}{l}\text { Stage II: Developing } \\
\text { (ovaries/ testis beginning } \\
\text { to grow and develop, but } \\
\text { fish not ready to spawn/ } \\
\text { for sperm emission) }\end{array}$ & $\begin{array}{l}\text { Enlarging ovaries, less transparent, better } \\
\text { vascularized, and yellowish. Some oocytes } \\
\text { visible to the naked eye, blood vessels } \\
\text { becoming more distinct. }\end{array}$ & $0.47 \pm 0.08$ & $\begin{array}{l}\text { Small milky white } \\
\text { testicles easily } \\
\text { identifiable with a } \\
\text { flattened section leaving } \\
\text { any liquid to drain from } \\
\text { the incision. }\end{array}$ & $0.39 \pm 0.08$ \\
\hline $\begin{array}{l}\text { Stage III: Spawning } \\
\text { capable (fish are } \\
\text { developmentally and } \\
\text { physiologically able to } \\
\text { spawn in this cycle/ fluent } \\
\text { milt) }\end{array}$ & $\begin{array}{l}\text { Ovaries are orange-yellow and very large; } \\
\text { highly vascularized especially in the lower } \\
\text { part, perfectly individualized translucent } \\
\text { eggs with a clear cytoplasmic membrane } \\
\text { which are expelled with the slightest } \\
\text { pressure on the abdomen. Bloods vessels } \\
\text { prominent. }\end{array}$ & $5.12 \pm 1.91$ & $\begin{array}{l}\text { Large and firm testes, } \\
\text { knife-blade-like leaving } \\
\text { whitish semen flow from } \\
\text { the incision and pressure } \\
\text { on the abdomen. }\end{array}$ & $5.72 \pm 2.25$ \\
\hline $\begin{array}{l}\text { Stage IV: Regressing } \\
\text { (cessation of spawning) }\end{array}$ & $\begin{array}{l}\text { Vascularized empty and flabby orange-red } \\
\text { ovaries, bloods vessels prominent. }\end{array}$ & $1.55 \pm 0.77$ & $\begin{array}{l}\text { Large and soft testes } \\
\text { releasing milt with many } \\
\text { lumps. }\end{array}$ & $3.55 \pm 1.46$ \\
\hline $\begin{array}{l}\text { Stage V: Regenerating } \\
\text { (sexually mature fish but } \\
\text { reproductively inactive) }\end{array}$ & $\begin{array}{l}\text { Flaccid inactive ovaries much reduced } \\
\text { volume with no abdominal pressure and } \\
\text { richly vascularized, red dark, with brown } \\
\text { spots corresponding to areas sclerosis or } \\
\text { residual atretic oocytes. }\end{array}$ & $0.88 \pm 0.52$ & $\begin{array}{l}\text { Testes are exhausted } \\
\text { and richly vascularized } \\
\text { leaving traces of semen } \\
\text { flowing out, giving the } \\
\text { organ a curdled milk } \\
\text { appearance. }\end{array}$ & $0.64 \pm 1.94$ \\
\hline
\end{tabular}




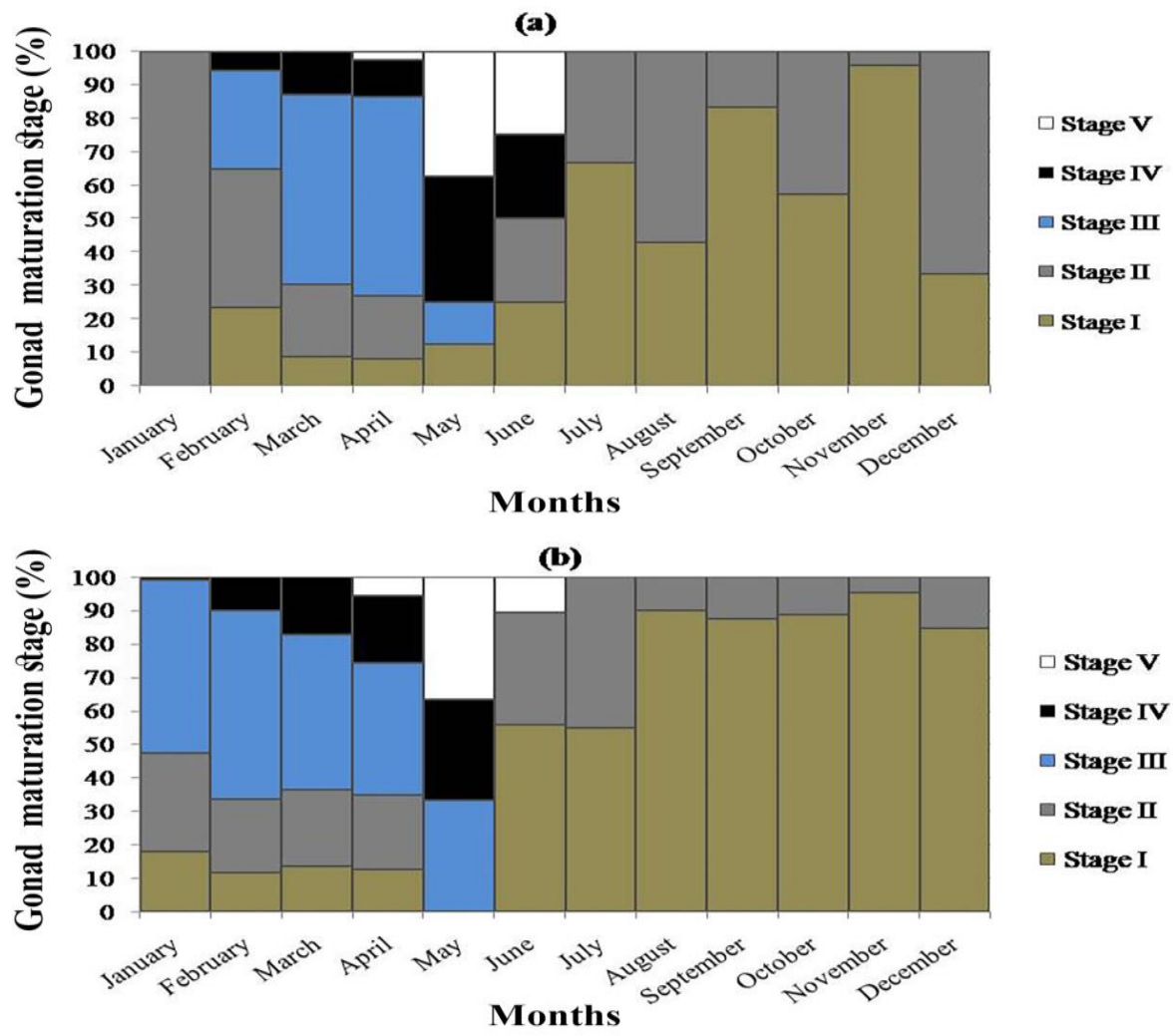

Figure 6. Monthly evolution of the sexual maturity stages (\%) of $D$. sargus sargus females (a) and males (b). Stage I (immature), Stage II (developing), Stage III (spawning capable), Stage IV (regressing), Stage V (regenerating)

fluctuated around $1 \%$ in both sexes and its lowest values were recorded during the resting period in July for males $(0.77 \pm 0.17)$ and in December $(0.84 \pm 0.11)$ for females. In the case of $\mathrm{HSI}$, the difference between the mean values according to months was also significant for females (Kruskal-Wallis rank sum test, $\mathrm{H}=58.895, \mathrm{df}=11$, $\mathrm{P}<0.001$ ) and males (Kruskal-Wallis rank sum test, $\mathrm{H}=27.679, \mathrm{df}=11, \mathrm{P}<0.05)$. Mean condition index values showed a stable monthly trend for both sexes. There was no significant variation in this index from one month to another for males (Kruskal-Wallis rank sum test, $H=37.798, d f=11, P>0.05)$ and females (Kruskal-Wallis rank sum test, $\mathrm{H}=31.182, \mathrm{df}=11, \mathrm{P}>0.05)$. However, the most overweight fish were recorded in October for females $(1.69 \pm 0.16)$ and males $(1.72 \pm 0.05)$ (Figure $8 \mathrm{c}$ ), except this month showed slight fluctuations. The least overweight fish were observed in July for females (1.28 \pm 0.35$)$. Correlations between different indices were examined for each sex separately and between sexes. For males, a low positive correlation was found between the variations of GSI and HSI (Pearson, $r=0.551$, $\mathrm{P}>0.05$ ) and GSI and K (Pearson, $r=0.489, \mathrm{P}>0.05$ ) but a high negative correlation between $\mathrm{HSI}$ and $\mathrm{K}$ (Pearson, $r=-0.786, P<0.05)$. For females, $\mathrm{GSI}$ and $\mathrm{HSI}$ fluctuations were positively correlated (Pearson, $r=0.781, P<0.05$ ), but negative results were obtained when comparing $\mathrm{HSI}$ and $\mathrm{K}$ (Pearson, $\mathrm{r}=-0.646, \mathrm{P}<0.05$ ) and $\mathrm{GSI}$ and $\mathrm{K}$ (Pearson, $\quad r=-0.511, \quad P<0.05)$. The between-sexes comparison of the biophysiological indices revealed a very high positive correlation between GSI (Pearson, $r=0.946, P<0.001)$, but low positive correlations for HSI (Pearson, $r=0.518, P<0.05$ ) and $K$ (Pearson, $r=0.472$, $\mathrm{P}<0.05)$.

\section{Fecundity}

The study of the frequency distributions of oocyte diameters showed distinct oocyte batches (Figure 9a). The first group represented the reserve oocyte batch (Figure 9b), which extended from 50 to $140 \mu \mathrm{m}$ in diameter with an average value of $89 \pm 5 \mu \mathrm{m}$. Therefore, the eggs that participated in the releasing of the actual season of $D$. sargus sargus were those with a diameter greater than $140 \mu \mathrm{m}$. The second group of oocytes was characterised by diameters ranging from 140 to $290 \mu \mathrm{m}$ with a mean of $229 \pm 6 \mu \mathrm{m}$, while the third group included oocytes ranging from 290 to $440 \mu \mathrm{m}$ with an average value of $369 \pm 7 \mu \mathrm{m}$ and representing $25 \%$ of the distribution. The fourth batch contained oocytes ranging from 440 to $500 \mu \mathrm{m}$ with an average diameter of $471 \pm 5$ $\mu \mathrm{m}$. Finally, the last group was the most important, accounting for $55 \%$ of the distribution, and was composed of mature oocytes whose diameter ranged from 500 to $800 \mu \mathrm{m}$ with a mean of $582 \pm 5 \mu \mathrm{m}$. However, in the present study, the presence of oocytes from all developmental stages in this species may indicate an indeterminate fecundity type. A significant difference was recorded for all mean oocyte diameters of the five oocyte cohorts (ANOVA, $\mathrm{F}=2572.3, \mathrm{P}<0.001$ ). Moreover, theses mean diameters were distinct from each another 
(Tukey HSD test, $\mathrm{P}<0.001$ ). The values of the mean oocyte diameter of the anterior, middle, and posterior portions of the ovary did not vary significantly (ANOVA, $F=0.055, P=0.995)$. Similarly, the differences between lobes were not significant (ANOVA, $F=0.085, P=0.977$ ); therefore, all samples were combined for the estimation of the absolute fecundity. Individual absolute fecundity estimates ranged from 70200 to 550000 eggs for females ranging between $24.4 \leq \mathrm{TL} \leq 40.3 \mathrm{~cm}$ and weighing between $244.59 \leq \mathrm{TW} \leq 1135.77 \mathrm{~g}$ and $5.12 \leq$
$\mathrm{GW} \leq 100.29 \mathrm{~g}$. The mean value for absolute fecundity was $186570 \pm 5990$ eggs for a female whose mean total length was $27.07 \pm 1.32 \mathrm{~cm}$ with a mean total weight of $363.11 \pm 62.19 \mathrm{~g}$ and a mean gonad weight of $17.87 \pm 5.57$ g. The relationships between absolute fecundity (Fa) and total length (TL), total weight (TW), and gonad weight (GW) were described by linear and power equations, as shown in Table 6 . The correlation coefficients were high and indicated that fecundity increased with these parameters. The linear model

Table 5. Microscopic descriptions of the phases in the reproductive cycle of $D$. sargus sargus females.

\begin{tabular}{|c|c|c|}
\hline Stages & Microscopic features & $\mathrm{NI} \pm \mathrm{SE}$ \\
\hline Stage I : Immature & $\begin{array}{l}\text { Only oogonia ( } 18.55 \pm 3.32 \mu \mathrm{m}) \text { and primary growth oocytes (PG) }(40.32 \pm 7.28 \\
\mu \mathrm{m}) \text { are present in the ovary. Thin ovarian wall and little space between } \\
\text { oocytes. }\end{array}$ & $0.52 \pm 0.012$ \\
\hline Stage II : Developing & $\begin{array}{l}\text { Initial vitellogenic oocytes (Vtg1) }(138.77 \pm 12.41 \mu \mathrm{m}) \text { are present with } \\
\text { secondary vitellogenic oocytes }(\mathrm{Vtg} 2)(263.55 \pm 9.17 \mu \mathrm{m}) \text { in ovaries. }\end{array}$ & $0.34 \pm 0.009$ \\
\hline Stage III : Spawning capable & $\begin{array}{l}\text { Tertiary vitellogenic oocytes }(\mathrm{Vtg} 3)(522.77 \pm 14.72 \mu \mathrm{m}) \text {, germinal vesicle } \\
\text { migration }(\mathrm{GVM})(383.65 \pm 7.58 \mu \mathrm{m}) \text { and hydrated follicle }(\mathrm{H}) \text { are present in } \\
\text { batch spawners. }\end{array}$ & $0.18 \pm 0.011$ \\
\hline $\begin{array}{l}\text { Stage IV : Regressing (cessation of } \\
\text { spawning) }\end{array}$ & $\begin{array}{l}\text { Later stages of hydrated follicle }(\mathrm{H}) \text {, atretic oocytes (ATR) and postovulatory } \\
\text { follicle complex (POF) present. }\end{array}$ & - \\
\hline $\begin{array}{l}\text { Stage V: Regenerating (sexually } \\
\text { mature, reproductively inactive) }\end{array}$ & $\begin{array}{l}\text { Only oogonia }(10.25 \pm 2.64 \mu \mathrm{m}) \text { and primary growth oocytes }(22.32 \pm 5.87 \\
\mu \mathrm{m}) \text { are present in the ovary with thick ovarian wall. }\end{array}$ & $0.37 \pm 0.021$ \\
\hline
\end{tabular}

$\mathrm{NI}$ : Nucleoplasmic index, SE = standard error of nucleoplasmic index, $\mathrm{H}=$ hydrated follicle, $\mathrm{GVM}=$ germinal vesicle migration, $\mathrm{PG}=$ primary growth, $\mathrm{Vtg} 1$ = primary vitellogenic, $\mathrm{Vtg} 2=$ secondary vitellogenic, $\mathrm{Vtg} 3=$ tertiary vitellogenic, $\mathrm{ATR}=$ atretic oocytes, POF $=$ postovulatory follicle .

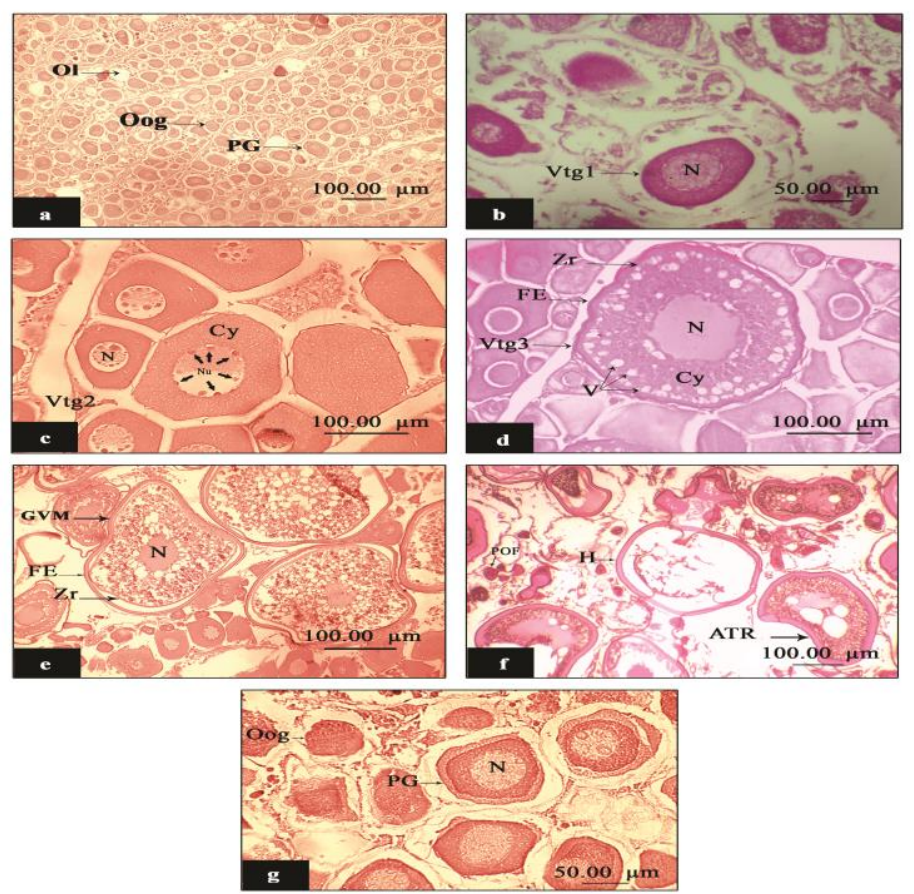

Figure 7. Transverse sections of ovaries in white seabream at different developmental stages of ovogenesis. a. General view of immature ovary (Stage I). b. Developing female containing primary vitellogenic oocytes (Stage II). c. Early maturing stage with secondary vitellogenic oocytes with numerous nucleoli. d. Spawning capable stage showing spent ovaries with tertiary vitellogenic oocytes (Stage III). e. Mature female containing germinal vesicle migration. f. Regressing stage with hydrated follicle, atretic oocytes and postovulatory follicle complex. g. Regenerating stage with oogonia and primary growth oocytes. Abbreviations: Ol = ovarian lumen, $\mathbf{O o g}=$ oogonia, $\mathbf{P G}=$ primary growth oocytes, $\mathbf{N}=$ nucleus, $\mathbf{N u}=$ nucleoli, $\mathbf{C y}=$ cytoplasm, $\mathbf{V t g} \mathbf{1}=$ primary vitellogenic oocyte, $\mathbf{V t g} \mathbf{2}=$ secondary vitellogenic oocyte, $\mathbf{V t g} \mathbf{3}=$ tertiary vitellogenic oocyte, $\mathbf{G V M}=$ germinal vesicle migration, $\mathbf{V}=$ vacuole, $\mathrm{Zr}=$ zona radiata, $\mathrm{FE}=$ follicular epithelium, $\mathrm{POF}=$ post ovulatory follicle, $\mathrm{ATR}=$ atretic follicle. 


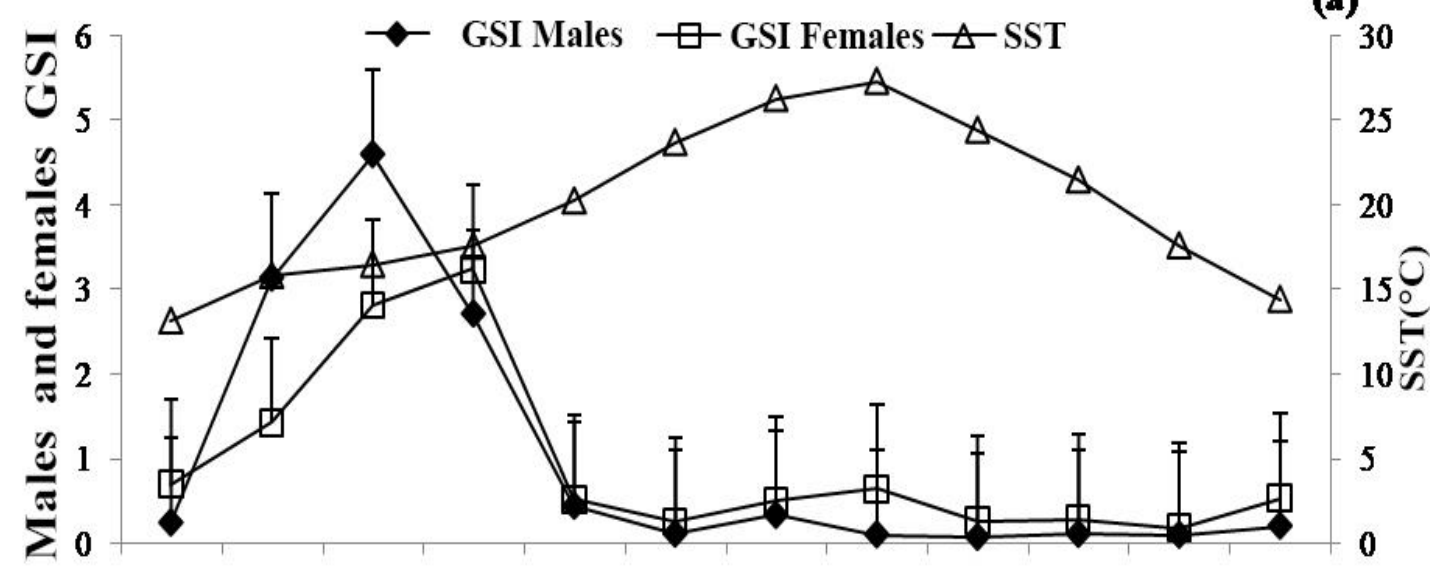

(a)
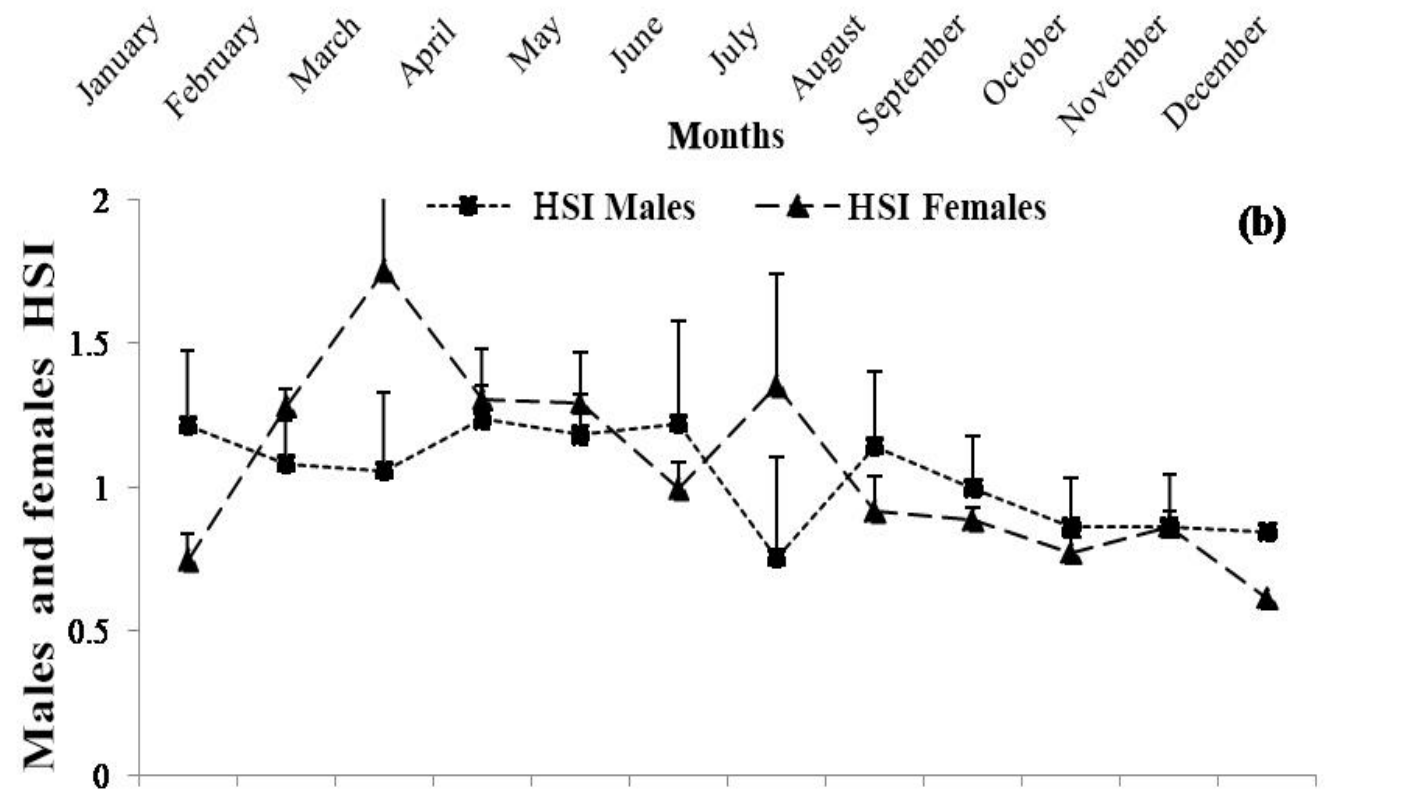

(b)

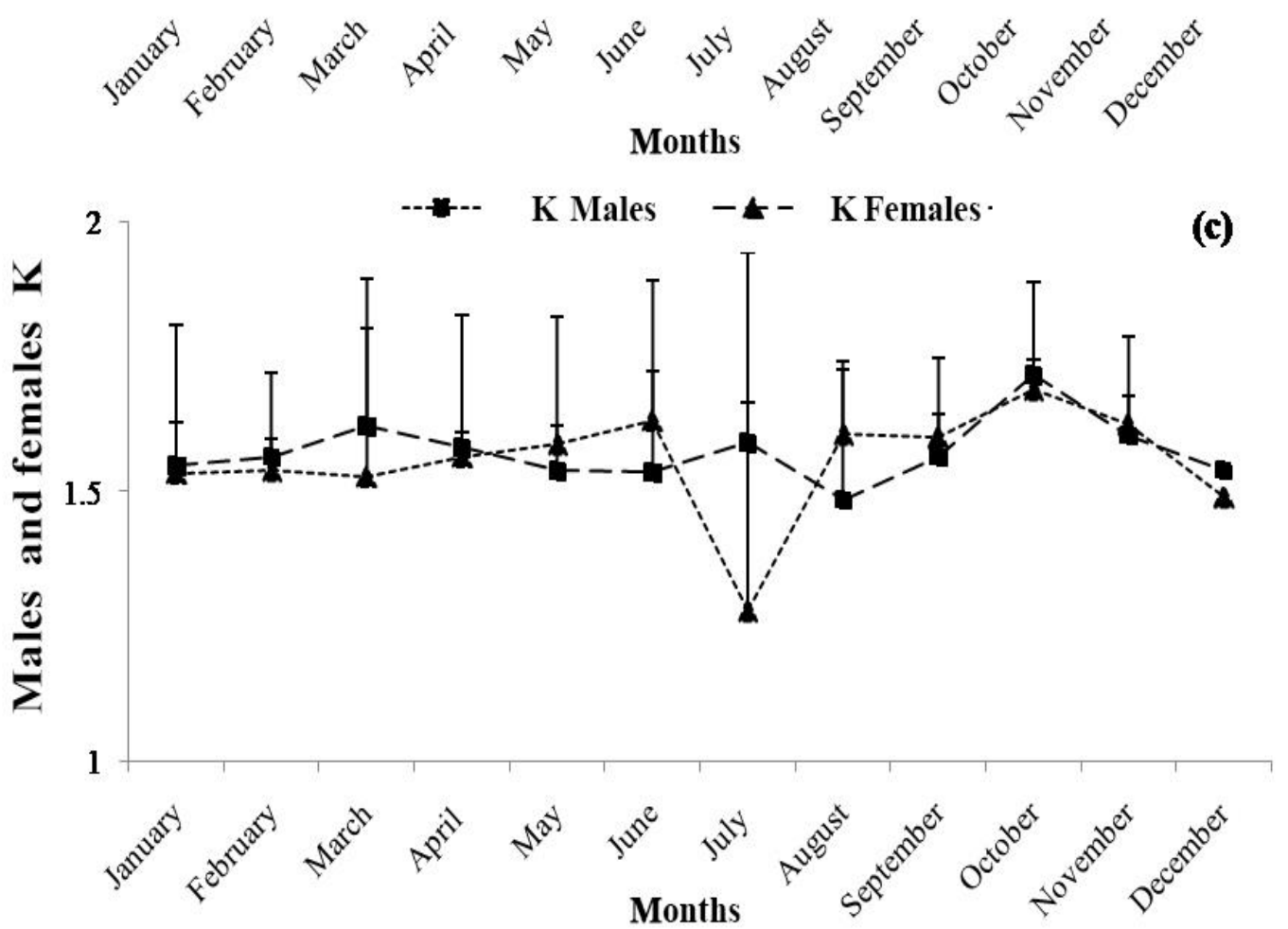

Figure 8. Mean monthly values of sea surface temperature (SST ${ }^{\circ} \mathrm{C}$ ) and gonadosomatic index (GSI) (a), hepatosomatic index (HSI) (b) and condition factor (K) (c) of D. sargus sargus males and females in the central Algerian coast. Error bars: standard deviations. 


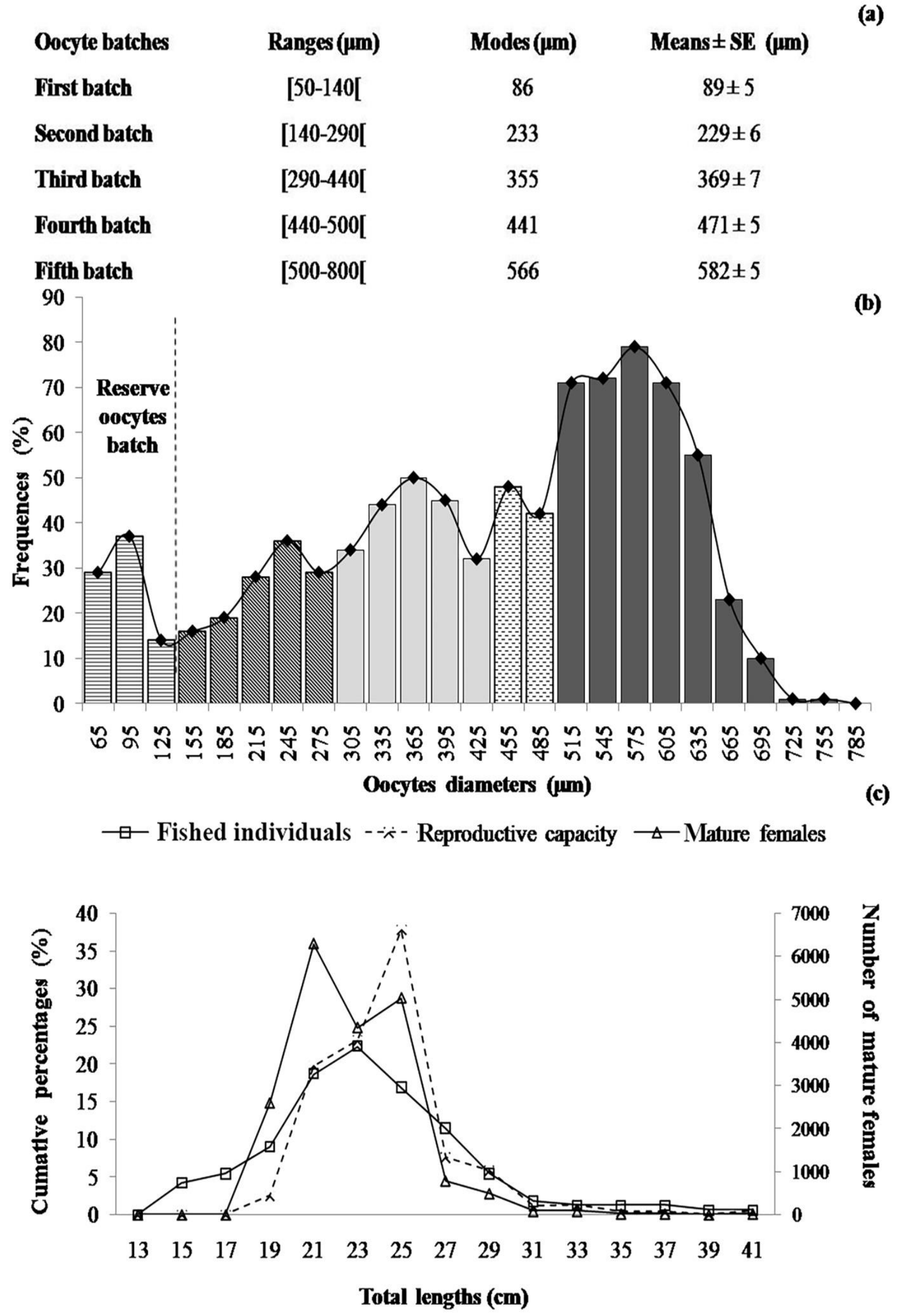

Figure 9. Ranges, means and modal values of oocytes batches (a) and oocyte diameter frequency distribution (b) and reproductive capacity (c) of Diplodus sargus sargus mature females in the central Algerian coast (southern Mediterranean Sea). SE $=$ standard error 
seemed to better express the association degree between the studied factors (Pearson's correlation ( $r$ ), $\mathrm{P}<0.001$ ). Relative fecundity varied from 118 to 1024 eggs per gram of body weight and ranged from 177 to $1136 \mathrm{~g}$, with a mean value of $573 \pm 63$ eggs. $\mathrm{g}^{-1}$. Regarding the global fecundity of $D$. sargus sargus (Figure 9c), the curve of fished individuals was slightly behind the curve of reproductive capacity. Non-mature male and female individuals ranging from 13 to $19 \mathrm{~cm}$ did not contribute to the global fecundity of this sparid fish. All fished females with a size between 13 and $17 \mathrm{~cm}$ and those mature between 27 and $41 \mathrm{~cm}$ contributed to the reproductive potential and stock renewal of this species. Females between 21 and $41 \mathrm{~cm}$ in size had a significant contribution in the reproductive capacity of the species with $88 \%$ of egg production. The most productive length-class concern fish were those whose size ranged from 23 to $33 \mathrm{~cm}$.

\section{Discussion}

The determination of the so-called 'cube law' is important, as it can be used for the evaluation of a stock exploitation status in fisheries management, as reference data for species with no previous LWRs and for comparison between populations. On the central Algerian coast, positive allometric growth was found between weight and length for males and hermaphrodites, but isometric growth was seen in females and pooled sexes. Similar somatic growth was reported in the Mediterranean Sea by many authors (Benchalel \& Kara, 2013; Man-Wai \& Quignard, 1982; Mouine et al., 2007) and in the Atlantic Ocean by Morato et al., (2001) in the Azores (Table 7). In the central Algerian coastline, the proportion of bisexual individuals detected after macroscopic sex determination was considerably higher (21.25\%) when compared to the percentage recorded on the Eastern Algerian coast (2\%) by Benchalel and Kara (2013), in Northern Spain (5.6\%) by Martinez-Pastor and VillegasCuadros, (1996), and in the Gulf of Tunis (6.4\%) by Mouine et al. (2007). Combining macroscopic and microscopic sex identification, bisexual individuals represented $23 \%$ on the Egyptian coast (El-Maghraby et al., 1981, 1982) and 50\% in the Gulf of Lion (Man-Wai, 1985). It appeared that the estimated hermaphroditic fraction of the various populations of white seabream depends largely on the methods used by the different authors to determine sex.

The sex ratio (M:F) was in favour of females for white seabream populations in the Canary Islands (Pajuelo \& Lorenzo, 2004 [1:2.90]), the Mediterranean Sea (Benchalel \& Kara, 2013 [1:1.36]; Mouine et al., 2007 [1:2.92], 2012 [1:2.24]), and the Atlantic Ocean (Mann \& Buxton, 1998 [1:1.98]; Morato et al., 2003 [1:1.93]). However, in the present study, the sex ratio of D. sargus sargus was skewed toward males. Currently, unbalanced global sex ratios may be related to the presence of sexual divergence and inequality in terms of growth, mortality renewal of reproductive potential, and behaviour towards fishing gear. Additionally, Pla et al. (2020) stated that male-skewed sex ratios were observed in populations of protandrous species, and this hypothesis is the most probable explanation of the significant dominance of males in the white seabream population of the central Algerian coast.

The bipotentiality of Sparidae gonads gives this species a reproductive plasticity. Buxton and Garratt (1990) reviewed the reproductive strategies of Sparidae and suggested that in species with a sequential hermaphroditism, the male and female mean sizes and gonadosomatic indices were significantly different and their size frequencies were bimodal. However, in species with a rudimentary hermaphroditism, sexes had similar mean sizes and gonadosomatic indices, and their lengthfrequency distributions overlaps were similar. On the central Algerian coast, males and females of $D$. sargus sargus presented significant differences between their mean size and GSI, and their size frequencies were bimodal. Moreover, a predominance of males in the small size classes and the clear dominance of females in the large size classes, coupled with the observation of bisexual individuals, unequivocally indicates a protandrous sequential hermaphroditism of the local population. An additional argument supporting protandry is detection, by microscopic observation of gonads, of a developing ovarian tissue and testicular degenerating tissue in bisexual individuals between 24.3 and $28.9 \mathrm{~cm}$. This protandric pattern of sex change was also reported by many other authors (Abou-Seedo et al., 1990; Benchalel \& Kara, 2013; Micale et al., 1987; Micale \& Perdichizzi, 1994). However, rudimentary

Table 6. Linear and power models of the relationships between absolute fecundity (Fa) and total length (TL), total weight (TW) and gonad weight (GW) of D. sargus sargus in the central Algerian coast.

\begin{tabular}{|c|c|c|c|c|c|c|}
\hline \multirow{2}{*}{ Parameters } & \multirow{2}{*}{$\begin{array}{l}\text { Linear Model } \\
\mathrm{Y}=\mathrm{a} \mathbf{X}+\mathbf{b}\end{array}$} & \multicolumn{2}{|c|}{ Pearson's correlation } & \multirow{2}{*}{$\begin{array}{l}\text { Power model } \\
Y=a X^{b}\end{array}$} & \multicolumn{2}{|c|}{ Pearson's correlation } \\
\hline & & $r$ & $\mathbf{P}$ & & $r$ & $\mathbf{P}$ \\
\hline \multirow[t]{2}{*}{ Total fish length (TL) } & $\mathrm{Fa}=19482 \mathrm{TL}-31565^{*}$ & & & $\mathrm{Fa}=229 \mathrm{TL}^{2.06 *}$ & & \\
\hline & $\mathrm{Fa}=22391 \mathrm{TL}-405835^{* *}$ & 0.961 & $<0.001$ & $\mathrm{Fa}=76 \mathrm{TL}^{2.38 * *}$ & 0.956 & $<0.001$ \\
\hline \multirow[t]{2}{*}{ Total weight (TW) } & $\mathrm{Fa}=332 \mathrm{TW}+47562^{*}$ & & & $\mathrm{Fa}=5305 \mathrm{TW}^{0.6 *}$ & & \\
\hline & $\mathrm{Fa}=444 \mathrm{TW}-27595^{* *}$ & 0.875 & $<0.001$ & $\mathrm{Fa}=462 \mathrm{TW} 0.98 * *$ & 0.808 & $<0.001$ \\
\hline \multirow[t]{2}{*}{ Gonad weight (GW) } & $\mathrm{Fa}=3465 \mathrm{GW}+10023^{*}$ & & & $\mathrm{Fa}=57521 \mathrm{GW}^{0.4 *}$ & & \\
\hline & $\mathrm{Fa}=4080 \mathrm{GW}+68289 * *$ & 0.915 & $<0.001$ & $\mathrm{Fa}=40889 \mathrm{GW} 0.5 * *$ & 0.891 & $<0.001$ \\
\hline
\end{tabular}

$\mathrm{r}=$ correlation coefficient, $\mathrm{P}=$ p.value of Pearson's correlation, ${ }^{*}=$ relation of the least squares type, ${ }^{* *}=$ relation of the least rectangles type 
Table 7. Parameters of length-weight relationships of Diplodus sargus sargus in different localities of the Mediterranean Sea and the Atlantic Ocean.

\begin{tabular}{|c|c|c|c|c|c|c|c|c|c|c|}
\hline Authors & $\begin{array}{l}\text { Regions/ } \\
\text { Country }\end{array}$ & Sex & $a$ & $b$ & $r^{2}$ & n & $L_{\min }$ & $\mathrm{L}_{\max }$ & $\begin{array}{l}\text { Sampling } \\
\text { period }\end{array}$ & $\begin{array}{l}\text { Type of } \\
\text { growth }\end{array}$ \\
\hline $\begin{array}{l}\text { Mai-Wai and } \\
\text { Quignard (1982) }\end{array}$ & $\begin{array}{l}\text { Gulf of Lion } \\
\text { (France) }\end{array}$ & $C$ & 0.017 & 3.09 & 0.935 & 484 & 6.0 & 42.0 & $\begin{array}{l}\text { January to } \\
\text { December } \\
1980\end{array}$ & Isometry \\
\hline $\begin{array}{l}\text { Morato et al. } \\
(2001)\end{array}$ & $\begin{array}{l}\text { Azores } \\
\text { (Portugal) }\end{array}$ & $\begin{array}{l}\mathrm{F} \\
\mathrm{M} \\
\mathrm{C}\end{array}$ & $\begin{array}{l}0.0166 \\
0.0180 \\
0.0111\end{array}$ & $\begin{array}{l}3.054 \\
3.032 \\
3.181\end{array}$ & $\begin{array}{l}0.970 \\
0.961 \\
0.997\end{array}$ & $\begin{array}{l}446 \\
231 \\
117 \\
8\end{array}$ & $\begin{array}{l}12.2 \\
9.2 \\
1.7\end{array}$ & $\begin{array}{l}41.1 \\
39.8 \\
41.1\end{array}$ & $\begin{array}{l}\text { June } 1997 \text { to } \\
\text { December } \\
1999\end{array}$ & $\begin{array}{l}\text { Isometry } \\
\text { Isometry } \\
\text { Isometry }\end{array}$ \\
\hline $\begin{array}{l}\text { Mouine et al. } \\
(2007)\end{array}$ & $\begin{array}{l}\text { Gulf of Tunis } \\
\text { (Tunisia) }\end{array}$ & $\begin{array}{l}\mathrm{F} \\
\mathrm{M} \\
\mathrm{C}\end{array}$ & $\begin{array}{l}0.018 \\
0.012 \\
0.015\end{array}$ & $\begin{array}{l}2.994 \\
3.129 \\
3.051\end{array}$ & $\begin{array}{l}0.985 \\
0.983 \\
0.984\end{array}$ & $\begin{array}{l}108 \\
37 \\
247\end{array}$ & $\begin{array}{l}15.5 \\
15.8 \\
11.2\end{array}$ & $\begin{array}{l}37.2 \\
30.0 \\
37.2\end{array}$ & $\begin{array}{l}\text { September } \\
2002 \text { to } \\
\text { February } \\
2004\end{array}$ & $\begin{array}{l}\text { Isometry } \\
\text { Isometry } \\
++++\end{array}$ \\
\hline \multirow[t]{3}{*}{$\begin{array}{l}\text { Benchalel and } \\
\text { Kara (2012) }\end{array}$} & $\begin{array}{l}\text { Eastern } \\
\text { Algerian coast }\end{array}$ & $\mathrm{F}$ & $\begin{array}{l}2.7210^{-} \\
5\end{array}$ & 2.945 & 0.980 & 98 & 15.4 & 34.6 & $\begin{array}{l}\text { December } \\
2005 \text { to }\end{array}$ & Isometry \\
\hline & (Algeria) & $\mathrm{M}$ & $\begin{array}{l}1.9010^{-} \\
5\end{array}$ & 3.009 & 0.980 & 143 & 11.2 & 33.0 & $\begin{array}{l}\text { December } \\
2006\end{array}$ & Isometry \\
\hline & & C & $\begin{array}{l}2.2410^{-} \\
5\end{array}$ & 2.987 & 0.980 & 241 & 11.2 & 34.6 & & Isometry \\
\hline Present study & $\begin{array}{l}\text { Central } \\
\text { Algerian coast } \\
\text { (Algeria) }\end{array}$ & $\begin{array}{l}\mathrm{F} \\
\mathrm{M} \\
\mathrm{C}\end{array}$ & $\begin{array}{l}0.019 \\
0.004 \\
0.021\end{array}$ & $\begin{array}{l}2.939 \\
3.492 \\
2.963\end{array}$ & $\begin{array}{l}0.989 \\
0.987 \\
0.990\end{array}$ & $\begin{array}{l}151 \\
190 \\
497\end{array}$ & $\begin{array}{l}13.4 \\
12.4 \\
12.4\end{array}$ & $\begin{array}{l}40.3 \\
31.1 \\
40.3\end{array}$ & $\begin{array}{l}\text { January to } \\
\text { December } \\
2017\end{array}$ & $\begin{array}{l}\text { Isometry } \\
++++ \\
\text { Isometry }\end{array}$ \\
\hline
\end{tabular}

$\mathrm{M}=$ males, $\mathrm{F}=$ females, $\mathrm{C}=$ sexes combined, $\mathrm{a}=$ intercept, $\mathrm{b}=$ slope, $\mathrm{r}^{2}=$ coefficient of determination, $\mathrm{n}=$ sample size, $\mathrm{Lmin}=$ minimum length in $\mathrm{cm}$, $\mathrm{L}_{\max }=$ maximum length in $\mathrm{cm},++++=$ positive allometry, $----=$ negative allometry.

hermaphroditism and facultative protandry were described in various populations of $D$. sargus sargus (Lissia-Frau, 1968; Man-Wai, 1985; Mouine et al., 2007; Tortonese, 1965). According to Gonçalves and Erzini (2000), the occurrence of partial protandry increases the number of larger females that are potentially more fecund, which is beneficial to populations in terms of spawning potential. Moreover, the optional protandry was documented by the detection of both primary and secondary females (digyny), as reported in the samples of the Gulf of Tunis (Mouine et al., 2007) and the Gulf of Castellammare (Giacalone et al., 2018). However, for other subspecies, such as $D$. sargus capensis of South Africa, $D$. sargus kotschyi of the Persian Gulf, and $D$. sargus cadenati from Spain and the Azores, digyny was also raised and considered as a common reproductive style of seabream species (Buxton \& Garratt, 1990); Mann \& Buxton, 1998). The percentage of $D$. sargus sargus individuals who changed sex was probably different between the various studied populations. It seems higher in the central sector of the Algerian coast as 1) a bimodal frequency distribution of sexes was observed, 2) males and females GSI were significantly different, and 3 ) the sex ratio was skewed towards males. These features are characteristic of a protandric population. This variable proportion of individuals changing sex was not surprising, as it is known that the control of sex reversal in populations is influenced by environmental (temperature, food availability) and/or social (demographic, behavioural) factors (Alekseev, 1983; Gibson, 1994; Shapiro, 1984; Warner, 1978). On the central Algerian coast, sexual inversion was observed for sizes between 12 and $30 \mathrm{~cm}$, corresponding to age classes between 2 and 7 years; however, on the Eastern Algerian coast, sexual inversion may occur from 2 to 5 years (Benchalel \& Kara, 2013). This high dispersion of sex change in a great range of age groups indicates that $D$. sargus sargus individuals change sex not only because they have reached a particular age (or size) but consecutively to alterations of their social system. For comparison, the estimation of the population median size of sexual inversion of $D$. sargus sargus on the central Algerian coast by Shapiro's method was $23.5 \mathrm{~cm}$, while it was of $22 \mathrm{~cm}$ for the population in Tunisian waters (Mouine et al., 2007). The implementation of workshops is recommended, with working groups including specialists in gonad histology and in the evaluation and monitoring of sex inversion phenomena. The goal would be to produce accurate methodologies for sex change and maturity determination and to standardise terminologies to obtain reliable data sets and minimise bias when the same species is studied by different teams in various other areas.

On the central Algerian coast, the sexual activity of D. sargus sargus takes place from January to May, and the spawning period extends from March to May with a peak in March and April. Benchalel and Kara (2013) and Mouine et al. (2007) reported similar results on the Southern coasts of the Mediterranean Sea. As the latitude decreased, the spawning period started earlier, and its duration increased from 3 to 5 months (Benchalel \& Kara, 2013; Mouine et al., 2007) . These regional dissimilarities have already been noticed and correlated with changes in thermal regimes (Morato et al., 2003) and a reduction of food activity (Benchalel et al., 2010). 
However, it is well known that latitude and water temperature have effects on sparids' spawning season (Sheaves, 2006). Furthermore, family spawning occurs over a small range of temperatures, initiating gonad maturation and spawning, so that production of larvae coincides when their planktonic prey is abundant (Bye, 1984). On the central Algerian coast, D. sargus sargus spawning took place between the SST range of $16-20^{\circ} \mathrm{C}$ after the winter season, which was also recorded in Spain (Martinez-Pastor \& Villegas-Cuadros, 1996; 13 $17^{\circ} \mathrm{C}$ ), South African coasts (Mann \& Buxton, 1998; 17 $20^{\circ} \mathrm{C}$ ), the Azores (Morato et al., 2003; $15-17^{\circ} \mathrm{C}$ ), and the Gulf of Tunis (Mouine et al., 2007; $15-18^{\circ} \mathrm{C}$ ). The male gonadosomatic index reached a peak one month before that of the female, which may be due to a competition strategy between males (Sousa et al., 2003). This hypothesis was supported by several authors, who reported that $D$. sargus males compete to fertilise eggs (Buxton \& Garratt, 1990; Gonçalves \& Erzini, 2000). Additionally, Pla et al. (2020) reported that high GSI values (> 3\%) in males were typically observed in species that spawned in large aggregations and that a handful of protandrous species engaged in promiscuous large groups where sperm competition was intense. This may be the case for $D$. sargus, as according to Aspillaga et al. (2016), D. sargus individuals were found to be highly territorial, moving within small home ranges $(<1$ $\mathrm{km}^{2}$ ). During the spawning season, they made excursions to deep areas (>50 m) where they aggregated to spawn. In the present study, the hepatosomatic index (HSI) showed significant variations from month to month, reflecting the important role of liver reserves during reproduction. HSI values of both sexes decreased, while GSI values increased. The periodicity of reproductive dynamics through its influence on the physiology of individuals conditioned the behaviour and biology of the species. However, Mouine et al. (2007) mentioned that the role of liver reserves during reproduction was not clear, and other methods were needed to determine whether hepatic reserves were mobilised for gonad maturation. In the central Algerian coast, the white seabream showed small fluctuations both in females and males and seemed to be affected by sexual activity. Moreover, Benchalel (2010) reported that the condition of the white seabream of the Eastern Algerian coast showed a seasonal cycle and was the best in summer and autumn and the worst in winter and spring. In this case, the condition was affected by sexual activity, density and variety of prey, and physical and chemical conditions of the environment, which strongly influenced their ability to grow, reproduce, and survive. In the central sector of the Algerian coastline, somatic growth presented a negative allometry. Likewise, Man-Wai (1985) mentioned a slimming of the white seabream from the Lion Gulf but after spawning. Conversely, Morato et al. (2003) reported a good condition during both spawning and post-spawning periods for the Azores population. However, the condition of $D$. sargus from the Egyptian coasts and the Northwestern Mediterranean Sea did not show significant differences during the reproductive cycle (El Maghraby et al., 1982; Lloret \& Planes, 2003).

In the central Algerian coast, size at first maturity ( $\left.T L_{50}\right)$ of the white seabream was $20.55 \mathrm{~cm}$. It was close to maturity sizes reported in the Eastern coast of Algeria $\left(T L_{50}=20 \mathrm{~cm}\right.$; Benchalel \& Kara, 2013), the Gulf of Tunis ( $\left(L_{50}=21 \mathrm{~cm}\right.$; Mouine et al., 2007), and in Northern Spain $\left(\mathrm{TL}_{50}=21 \mathrm{~cm}\right.$; Martinez-Pastor \& Villegas-Cuadros, 1996). However, the size at maturity of this study was lower than lengths found in South Africa ( $\mathrm{TL}_{50}=24.3 \mathrm{~cm}$; Mann \& Buxton, 1998) and the Gulf of Lion ( $\mathrm{TL}_{50 \%}=23 \mathrm{~cm}$; TL50\% $=20 \mathrm{~cm}$; (Man-Wai \& Quignard, 1982), but higher than that registered for the Azores $\left(\mathrm{TL}_{50}=16.7 \mathrm{~cm}\right.$; Morato et al., 2003) and Egyptian ( $\mathrm{TL}_{50}=18 \mathrm{~cm}$; El Maghraby et al., 1982) populations of $D$. sargus sargus. Then, large differences were observed in the acquisition of maturity between the $D$. sargus sargus populations. Even when the TL5o was similar, ages at first maturity were different. Size at maturity demonstrated a great plasticity and was likely to vary at the inter- or intra-population level; furthermore, its variations were generally explained by growth differences, with growth itself being regulated by environmental factors, such as temperature, resource availability, demographic structure, and sizeselective predation (Duponchelle \& Panfili, 1998). Size at maturity is an important parameter in fisheries management. The minimum landing size of the white seabream corresponded to $15 \mathrm{~cm}$, set by the Ministry of Fisheries and Fishery Resources of Algeria. This size was below the estimated $\mathrm{TL}_{50}$ of our study and should be increased to $20.55 \mathrm{~cm}$ for sustainable management. Additionally, for optimal preservation of the stock, fish may be caught after they have reached their size of the maximum growth rate in weight (Lopt), which corresponds to 0.67 of their theoretical maximum length (Rainer Froese et al., 2008). The obtained size was $27 \mathrm{~cm}$ (TL) and was similar to the calculated size $\left(\mathrm{TL}_{100}=30.75 \mathrm{~cm}\right)$ at which $100 \%$ of the total population of $D$. sargus sargus was mature. According to Froese (2004), the target would be to catch all white seabreams within $\pm 10 \%$ of their optimum length, corresponding in the present study to a size range of 24.3 to $29.7 \mathrm{~cm}$. The application of this last recommendation would maintain the ability for broodstock renewal in the long-term, while ensuring the rational management of the central Algerian artisanal fisheries stock. The reproductive load was usually smaller in large fish and larger in small fish (Froese \& Binohlan, 2000). The observed value of reproductive load for the studied species (0.51) was included in the range of $0.4-0.9$ compiled by (Froese \& Binohlan, 2000).

The knowledge of fecundity is seen as an important factor in understanding stock dynamics, not only to obtain an in-depth view of the mechanisms of reproduction but also to provide fundamental biological information for stock assessments and fisheries resource management. D. sargus sargus is a batch spawner with a multimodal group of oocyte diameter as 
recorded in P. acarne (Boufersaoui \& Harchouche, 2015) and B. boops (Amira et al., 2019) of the same family and study area. The oocyte diameter provided a distinction into four oocyte batches beyond the reserve oocytes batch of $140 \mu \mathrm{m}$. Split laying was detected from the oocyte diameter size-frequencies distribution of this species. Harchouche (2006) noted that some Sparidae fish can spawn several times during a single spawning period.

The individual absolute fecundity of the white seabream increased linearly with total length, total weight, and gonad weight and was highly correlated to these parameters. No differences in the size distribution of eggs were detected within the same lobe and between ovarian lobes of the gonads. For future studies, since oocyte development was uniform throughout the gonad, samples can be taken from any portion. Few available results about absolute and relative fecundity are found for this species in the Mediterranean Sea, but there is no available data on its reproductive capacity.

The histological analysis of ovaries from $D$. sargus sargus highlighted the simultaneous occurrence of previtellogenic, vitellogenic, and mature oocytes in spawning capable females. According to Neves et al.'s (2018) criteria, D. sargus sargus off the central Algerian coast may present an indeterminate fecundity type. Its absolute fecundity was $186570 \pm 5990$ eggs, while the relative fecundity was $573 \pm 63$ eggs. $\mathrm{g}^{-1}$. These results were significantly higher than those reported in the Egyptian coast (33665-168449 eggs) (Zaki et al., 2001) and in the East of Algeria (96741 \pm 62350 eggs; $270 \pm 109$ eggs. $\mathrm{g}^{-1}$ ) (Benchalel, 2010). These differences could depend on the methods used for fecundity estimation, the number and range sizes of female gonads sampled, and geographical variations (Boufersaoui \& Harchouche, 2015).

Fish populations were assessed and managed using length at first maturity and fecundity data to estimate the spawning stock biomass. Our results might be useful in helping sustainable exploitation of the resource by offering the scientific support needed to assess the current stock state. We suggest a limited catch length between 24.3 and $29.7 \mathrm{~cm}$ and a reduction of the fishing effort to ensure sustainable exploitation.

\section{Ethical Statement}

This study does not need any formal consent as the experimental fish, Diplodus sargus sargus is widely distributed in the central Algerian coast. The collection sites were not restricted areas but fishing is carried out commercially. The species is designated as 'least concern' by IUCN's Red List of threatened species. The study is in full compliance with the guidelines for laboratory animals and all relevant codes of experimentation, legality and legislation. All listed coauthors declare that the present study was conducted in an ethical, professional and responsible manner.

\section{Funding Information}

The authors received no financial support for the research, authorship, and/or publication of this article.

\section{Author Contribution}

BB: Conceptualization, Investigation, Methodology, Visualization, Data curation, Writing review and editing. NC-M: Conceptualization, Methodology, Writing - review and editing, Visualization, Supervision, Validation. EK: Investigation, Data analysis, Validation. ZA: Formal analysis, Validation, provided critical comments and final approval of the manuscript. SA: Formal analysis, Validation. KH: Writing - review and editing, Supervision.

\section{Conflict of Interest}

The authors declare that they have no known competing financial interests or personal relationships that could have appeared to influence the work reported in this paper.

\section{Acknowledgements}

We are grateful to the fishermen and scuba divers who provided us fresh specimens throughout the study period. We would also like to thank Dr. Bilel Bensari, who helped in fish collection, Dr. Mouloud Benabdi and Dr. Ghollame Ellah Yacine Khames for statistical advice, and Dr. Rym Bachetarzi and Prof. Fatiha Zerouali-Khodja for sharing their expertise in fish reproduction. The authors are deeply grateful to the anonymous reviewers for their constructive comments, critical reading, useful suggestions, and contributions for the improvement of the manuscript.

\section{References}

Abou-Seedo, F., Wright, J. M., \& Clayton, D. A. (1990). Aspect of the biology of Diplodus sargus kotschyi (Sparidae) from Kuwait bay. Cybium, 14, 217-223.

Albaret, J. J. (1977). La reproduction de l'albacore (Thunnus albacares) dans le golfe de Guinée. Cah.ORSTOM Ser. Oceanogr., 15(4), 389-419 (in French).

Alekseev, F. E. (1983). Hermaphroditism in Porgies (Perciformes, Sparidae). II. Sexual structure of the populations, mechanism of its formation and evolution in scups, Pagrus pagrus, $P$. orphus, $P$. ehrenbergi and $P$. auriga. Journal of Ichthyology, 23(2), 61-73.

Amira, S., Alioua, Z., \& Harchouche, K. (2019). Gonadal development and fecundity of bogue Boops boops (Linnaeus, 1758) (Sparidae) on the central Algerian coast. Turkish Journal of Zoology, 43(1), 12-29. https://doi.org/10.3906/zoo-1805-44

Aspillaga, E., Bartumeus, F., Linares, C., Starr, R. M., LópezSanz, À., Díaz, D., Zabala, M., \& Hereu, B. (2016). Ordinary and extraordinary movement behaviour of small resident fish within a mediterranean marine 
protected area. PLOS ONE, 11(7), 1-19. https://doi.org/10.1371/journal.pone.0159813

Bauchot, M. L., \& Hureau, J. C. (1986). Sparidae. In P. J. P. Whitehead, M. L. Bauchot, J. C. Hureau, J. Nielsen, \& E. Tortonese (Eds.), Fishes of the northeastern Atlantic and the Mediterranean (Vol. 2, pp. 883-907). Unesco, Paris, France.

Benchalel, W. (2010). Biologie et dynamique du sar commun Diplodus sargus sargus (Linnaeus, 1758) des côtes de l'Est Algérien . PhD Thesis. Université de Badji-Mokhtar, Annaba, Alger, Algérie, $191 \mathrm{pp}$ (in French).

Benchalel, W., Derbal, F., \& Kara, M. H. (2010). Régime alimentaire du sar commun Diplodus sargus sargus (Sparidae) des côtes de l'est algérien. Cybium, 34(3), 231-242 (in French).

Benchalel, W., \& Kara, M. H. (2013). Age, growth and reproduction of the white seabream Diplodus sargus sargus (Linneaus, 1758) off the eastern coast of Algeria. Journal of Applied Ichthyology, 29(1), 64-70. https://doi.org/10.1111/j.1439-0426.2012.02057.x

Boufersaoui, S., \& Harchouche, K. (2015). Dynamique de la reproduction et fécondité de Pagellus acarne (Sparidae) de la région Centre du littoral algérien. Cybium, 39(1), 59-69 (in French).

Brown-Peterson, N. J., Wyanski, D. M., Saborido-Rey, F., Macewicz, B. J., \& Lowerre-Barbieri, S. K. (2011). A standardized terminology for describing reproductive development in fishes. Marine and Coastal Fisheries, $3(1)$, https://doi.org/10.1080/19425120.2011.555724

Buxton, C. D., \& Garratt, P. A. (1990). Alternative reproductive styles in seabreams (Pisces: Sparidae). Environmental Biology of Fishes, 28(1-4), 113-124. https://doi.org/10.1007/BF00751031

Bye, V. J. (1984). The role of environmental factors in the timing of reproductive cycles. In R. J. Wooton \& G. W. Potts (Eds.), Fish Reproduction: Strategies and Tactics (pp. 132-148). Academic Press, London.

Dagnelie, P. (1984). Théorie et méthodes statistiques. Applications agronomiques. Presses agronomiques de Gembloux, Belgium, $463 \mathrm{pp}$ (in French).

Duponchelle, F., \& Panfili, J. (1998). Variations in age and size at maturity of female Nile tilapia, Oreochromis niloticus, populations from man-made lakes of Côte d'Ivoire. Environmental Biology of Fishes, 52(4), 453-465. https://doi.org/https://doi.org/10.1023/A:1007453731 509

El-Maghraby, A. M., Botros, G. A., Hashem, M. T., \& Wassef, E. A. (1981). Hermaphroditism in three sparid fish, Diplodus sargus L., Diplodus vulgaris, Geoffr. and Oblada melanura L. from the Egyptian Mediterranean waters. Bull. Inst. Oceanog. Fish. \& ARE., 7(3), 378-385.

El Maghraby, A. M., Botros, G. A., Hashem, M. T., \& Wassef, E. A. (1982). Maturation, spawning and fecundity of two sparid fish Diplodus sargus, L. and Diplodus vulgaris, Geoff. in the Egyptian Mediterranean waters. Bull. Inst. Oceanogr. Fish \& ARE, 8, 51-67.

Fischer, W., Bauchot, M. L., \& Schneider, M. (1987). Fiches FAO d'identification pour les besoins de la pêche. (Revision 1). Méditerranée et mer Noire. Zone de pêche 37. Vol. II. Vertébrés. FAO, Rome, pp. 761-1530 (in French).

Fontana, A., \& Le Guen, J. C. (1969). Etude de la maturité sexuelle et de la fécondité de Pseudotolithus (Foizticulzis) elongatus. Cah. ORSTOM. Ser. Oceanog., 7, 9-19.
Froese, R., \& Binohlan, C. (2000). Empirical relationships to estimate asymptotic length, length at first maturity and length at maximum yield per recruit in fishes, with a simple method to evaluate length frequency data. Journal of Fish Biology, 56(4), 758-773. https://doi.org/10.1006/jfbi.1999.1194

Froese, Rainer. (2004). Keep it simple: Three indicators to deal with overfishing. Fish and Fisheries, 5(1), 86-91. https://doi.org/10.1111/j.1467-2979.2004.00144.x

Froese, Rainer, Stern-Pirlot, A., Winker, H., \& Gascuel, D. (2008). Size matters: How single-species management can contribute to ecosystem-based fisheries management. Fisheries Research, 92(2-3), 231-241. https://doi.org/10.1016/j.fishres.2008.01.005

Giacalone, V. M., Ferreri, R., Micale, V., Pipitone, C., Basilone, G., Sacco, F. S., Mazzola, S., Bonanno, A., \& D'Anna, G. (2018). Evaluation of macroscopic maturity analysis with histology in the digynic protandrous hermaphrodite white seabream Diplodus sargus sargus (pisces, sparidae). Vie et Milieu, 68(2-3), 157-166.

Gibson, R. N. (1994). Impact of habitat quality and quantity on the recruitment of juvenile flatfishes. Netherlands Journal of Sea Research, 32(2), 191-206. https://doi.org/10.1016/0077-7579(94)90040-X

Gonçalves, J. M. S., \& Erzini, K. (2000). The reproductive biology of the two-banded sea bream (Diplodus vulgaris) from the SW Coast of Portugal. Journal of Applied Ichthyology, 16(3), 110-116. https://doi.org/https://doi.org/10.1046/j.14390426.2000.00232.x

Harchouche, K. (2006). Contribution à la systématique du genre Spicara: écologie, biologie et exploitation de Spicara maena (Poisson, Téléostéen) des côtes algériennes. PhD Thesis. Université des Sciences et de la Technologie Houari Boumediene, Alger, Algérie, 230 pp (in French).

Harmelin-Vivien, M. L., Harmelin, J. G., \& Lebouleux, V. (1995). Micro habitat requirements for settlement of juvenile sparid fishes on Mediterranean rocky shores. Hydrobiologia, 301, 309-320.

Kartas, F., \& Quignard, J. P. (1984). La fécondité des poissons téléostéens. Masson, Paris, France, 177 pp (in French).

Lissia-Frau, A. M. (1968). Le manifestazioni della sessualita negli Sparidi (Teleostei, Perciformes). Studi Sussaresi, 46, 243-261 (in Italian).

Lloret, J., \& Planes, S. (2003). Condition, feeding and reproductive potential of white seabream Diplodus sargus as indicators of habitat quality and the effect of reserve protection in the northwestern Mediterranean. Marine Ecology Progress Series, 248(2), 197-208. https://doi.org/10.3354/meps248197

Longhurst, A. R., \& Pauly, D. (1987). Ecology of tropical oceans. Academic Press, San Diego, USA, 470 pp.

Louisy, P. (2015). Guide d'identification des poissons marins Europe et Méditerranée. Ulmer, 520 pp.

Man-Wai, R. (1985). Les sars du Golfe de Lion. Diplodus sargus, $D$. vulgaris, D. annularis (Pisces, Sparidae): EcobiologiePêche. PhD Thesis. Université des Sciences et Techniques du Languedoc, Montpellier, France, 361 pp (in French).

Man-Wai, R., \& Quignard, J. P. (1982). Croissance linéaire et pondérale des jeunes Diplodus sargus $0+$ (Pisces, Osteichtyes, Sparidae) des étangs Languedociens de Mauguio et du Prévost. Rev. Trav. Inst. Pêches Marit., 45(4), 253-269 (in French). 
Mann, B. Q., \& Buxton, C. D. (1998). The reproductive biology of Diplodus sargus capensis and D. cervinus hottentotus (Sparidae) off the south-east cape coast, South Africa. Cybium, 22(1), 31-47.

Martinez-Pastor, C., \& Villegas-Cuadros, M. L. (1996). Edad, crecimiento y reproduccion de Diplodus sargus Linnaeus, 1758 (Sparidae) en aguas asturianas (norte de Espana). Bol. Inst. Esp.Oceanog., 12(1), 65-76 (in Spanish).

Micale, V., \& Perdichizzi, F. (1994). Further studies on the sexuality of the hermaphroditic teleost Diplodus sargus L., with particular reference to protandrous sex inversion. Journal of Fish Biology, 45(4), 661-670. https://doi.org/https://doi.org/10.1111/j.10958649.1994.tb00932.x

Micale, V., Perdichizzi, F., \& Santangelo, G. (1987). The gonadal cycle of captive white bream, Diplodus sargus (L.). Journal of Fish Biology, 31(3), 435-440. https://doi.org/10.1111/j.1095-8649.1987.tb05247.x

Morato, T., Afonso, P., Lourinho, P., Barreiros, J. P., Santos, R. S., \& Nash, R. D. M. (2001). Length-weight relationships for 21 coastal fish species of the Azores, north-eastern atlantic. Fisheries Research, 50(3), 297-302. https://doi.org/10.1016/S0165-7836(00)00215-0

Morato, T., Afonso, P., Lourinho, P., Nash, R. D. M., \& Santos, R. S. (2003). Reproductive biology and recruitment of the white sea bream in the Azores. Journal of Fish Biology, 63(1), 59-72. https://doi.org/10.1046/j.10958649.2003.00129.x

Mouine, N., Francour, P., Ktari, M. H., \& Chakroun-Marzouk, N. (2007). The reproductive biology of Diplodus sargus sargus in the Gulf of Tunis (central Mediterranean). Scientia Marina, 71(3), 461-469. https://doi.org/10.3989/scimar.2007.71n3461

Mouine, N., Francour, P., Ktari, M. H., \& Chakroun-Marzouk, N. (2012). Reproductive biology of four Diplodus species Diplodus vulgaris, $D$. annularis, $D$. sargus sargus and $D$. puntazzo (Sparidae) in the Gulf of Tunis (central Mediterranean). Journal of the Marine Biological Association of the United Kingdom, 92(3), 623-631. https://doi.org/10.1017/S0025315411000798

MPRH. (2017). Données statistiques sur la production nationale des ressources halieutiques au niveau du port d'Alger durant la période 2010-2016 (in French).

Murua, H., \& Saborido-Rey, F. (2003). Female reproductive strategies of marine fish species of the North Atlantic. Journal of Northwest Atlantic Fishery Science, 33(6), 2331. https://doi.org/10.2960/J.v33.a2

Neves, A., Vieira, A. R., Sequeira, V., Paiva, R. B., \& Gordo, L. S. (2018). Insight on reproductive strategy in Portuguese waters of a commercial protogynous species, the black seabream Spondyliosoma cantharus (Sparidae). Fisheries Research, 206(5), 85-95. https://doi.org/10.1016/j.fishres.2018.05.004

NOAA. (2017). National Centers for Environmental Information: National Oceanic and Atmospheric Administration: National Climatic Data Center. https://www.ncdc.noaa.gov

Ogle, D. H. (2019). FSAdata: Fisheries Stock Analysis, Datasets. $R$ package version 0.3.8.

Ogle, D. H., Wheeler, P., \& Dinno, A. (2019). FSA: Fisheries Stock Analysis. $R$ package version 0.8.26. https://github.com/droglenc/FSA

Oosthuizen, E., \& Daan, N. (1974). Egg fecundity and maturity of North Sea cod, gadus morhua. Netherlands Journal of
Sea Research, 8(4), 378-397. https://doi.org/10.1016/0077-7579(74)90006-4

Pajuelo, J. G., \& Lorenzo, J. M. (2004). Basic characteristics of the population dynamic and state of exploitation of Moroccan white seabream Diplodus sargus cadenati(Sparidae) in the Canarian archipelago. Journal of Applied Ichthyology, 20(1), 15-21. https://doi.org/10.1046/j.0175-8659.2003.00540.x

Pla, S., Benvenuto, C., Capellini, I., \& Piferrer, F. (2020). A phylogenetic comparative analysis on the evolution of sequential hermaphroditism in seabreams (Teleostei: Sparidae). Scientific Reports, 10(1), 1-12. https://doi.org/10.1038/s41598-020-60376-w

R Core Team. (2019). R: A Language and Environment for Statistical Computing. https://www.r-project.org

Saila, S. B., Recksiek, C. W., \& Prager, M. H. (1988). Basic fishery science programs: a compendium of microcomputer programs and manual of operation. Developments in Aquaculture and Fisheries Science. (Vol. 18). Elsevier Science, Amsterdam, $230 \mathrm{pp}$.

Sala, E., \& Ballesteros, E. (1997). Partitioning of space and food resources by three fish of the genus Diplodus (Sparidae) in a Mediterranean rocky infralittoral ecosystem. Marine Ecology Progress Series, 152, 273-283.

Schwartz, D. (1983). Méthodes statistiques à l'usage des médecins et des biologistes. Collection Statistique en biologie et en médecine. Flammarion, Paris, France, 199 $\mathrm{pp}$ (in French).

Shapiro, D. Y. (1984). Sex reversal and Sociodemographic Processes in Coral Reef Fishes. In G. W. Potts \& R. J. Wooton (Eds.), Fish Reproduction: Strategies and Tactics (pp. 103-117). Academic Limited Press.

Sheaves, M. (2006). Is the timing of spawning in sparid fishes a response to sea temperature regimes? Coral Reefs, 25(4), 655-669. https://doi.org/10.1007/s00338-0060150-5

Smith, T. M., \& Reynolds, R. W. (2003). Extended reconstruction of global sea surface temperatures based on COADS data (1854-1997). Journal of Climate, 16(10), 1495-1510. https://doi.org/10.1175/1520-044216.10.1495

Sousa, L., Barreiros, J. P., Soares, M. S. C., Hostim-Silva, M., \& Santos, R. S. (2003). Preliminary notes on the reproductive biology of the lizardfish, Synodus saurus (Actynopterygii: Synodontidae) in the Azores. Cybium, 27(1), 41-45.

Tortonese, E. (1965). II 'Sarago faraone' del Mediterraneo: Diplodus cervinus (LOWE) (Pisces, Sparidae). Doriana (Suppl. Ann. Mus. Stor. Nat. Gênes), 4, 1-7.

Tortonese, E., \& Cautis, I. (1967). Révision des poissons de la famille des Sparidés vivant près des côtes de Roumanie. Annal. Mus. Civ. Stor. Nat. Giacomo Doria, 77, 295-306 (in French).

Vigliola, L., \& Harmelin-Vivien, M. L. (2001). Post-set tlementontogeny in three Mediterranean reef fish species of the genus Diplodus. Bull. Mar. Sci., 68(2), 271286.

Warner, R. R. (1978). The evolution of hermaphroditism and unisexuality in aquatic and terrestical vertebrates. In $\mathrm{E}$. S. Reese \& F. J. Lighter (Eds.), Contrasts in Behaviour. (pp. 77-101). Wieley, New York, USA.

Whitehead, P. G. P., Bauchot, M. L., Hureau, J. C., Nielsen, J., \& Tortonese, E. (1986). Fishes of the north eastern Atlantic and the Mediterranean (Vol. 2, pp. 780-792). Unesco, Paris, France. 
Xue, Y., Smith, T. M., \& Reynolds, R. W. (2003). Interdecadal changes of 30-Yr SST normals during 1871-2000. Journal of Climate, 16(10), 1601-1612. https://doi.org/10.1175/1520-0442-16.10.1601
Zaki, M. I., Baghdadi, H. H., El-Gharabawy, M. M., \& El-Greisy, Z. A. (2001). Reproductive biology of Diplodus sargus (Family: Sparidae), in the Mediterranean environment. Rapp.Com. Int. Mer Med., 36, 336 pp. 